\title{
VEMAP Phase 2 bioclimatic database. I. Gridded historical (20th century) climate for modeling ecosystem dynamics across the conterminous USA
}

\author{
T. G. F. Kittel ${ }^{1,2,5, *}$, N. A. Rosenbloom ${ }^{1}$, J. A. Royle ${ }^{1,6}$, C. Daly ${ }^{3}$, W. P. Gibson ${ }^{3}$, \\ H. H. Fisher ${ }^{1}$, P. Thornton ${ }^{1}$, D. N. Yates ${ }^{1}$, S. Aulenbach ${ }^{1}$, C. Kaufman ${ }^{1}$, R. McKeown ${ }^{2}$, \\ D. Bachelet ${ }^{4}$, D. S. Schimel ${ }^{1}$, VEMAP2 Participants ${ }^{+}$ \\ ${ }^{1}$ National Center for Atmospheric Research, PO Box 3000, Boulder, Colorado 80307, USA \\ ${ }^{2}$ Natural Resource Ecology Laboratory, Colorado State University, Fort Collins, Colorado 80523, USA \\ ${ }^{3}$ Spatial Climate Analysis Service and ${ }^{4}$ Department of Bioengineering, Oregon State University, Corvallis, Oregon 97331, USA \\ Present addresses: ${ }^{5}$ INSTAAR, Campus Box 450, University of Colorado, Boulder, Colorado 80309-0450, USA \\ ${ }^{6}$ USDI Fish and Wildlife Service, Laurel, Maryland 20708, USA

\begin{abstract}
${ }^{+}$R. Neilson, J. Lenihan, R. Drapek (USDA Forest Service, Pacific Northwest Research Station, Corvallis, OR, USA); D. S. Ojima, W. J. Parton (Natural Resource Ecology Laboratory, Colorado State University, Fort Collins, CO, USA); J. M. Melillo, D. W. Kicklighter, H. Tian (Ecosystems Center, Marine Biological Laboratory, Woods Hole, MA, USA); A. D. McGuire (US Geological Survey, Alaska Cooperative Fish and Wildlife Research Unit, Fairbanks, AK, USA); M. T. Sykes, B. Smith, S. Cowling, T. Hickler (Physical Geography \& Ecosystems Analysis, Lund University, Sweden); I. C. Prentice (Max Planck Institute for Biogeochemistry, Jena, Germany); S. Running (University of Montana, Missoula, MT, USA); K. A. Hibbard (College of Forestry, Oregon State University, Corvallis, OR, USA); W. M. Post, A. W. King (Oak Ridge National Laboratory, Oak Ridge, TN, USA); T. Smith, B. Rizzo (Dept. of Environmental Sciences, University of Virginia, Charlottesville, VA, USA); F. I. Woodward (Dept. of Animal and Plant
\end{abstract} \\ Sciences, University of Sheffield, UK)
}

\begin{abstract}
Analysis and simulation of biospheric responses to historical forcing require surface climate data that capture those aspects of climate that control ecological processes, including key spatial gradients and modes of temporal variability. We developed a multivariate, gridded historical climate dataset for the conterminous USA as a common input database for the Vegetation/Ecosystem Modeling and Analysis Project (VEMAP), a biogeochemical and dynamic vegetation model intercomparison. The dataset covers the period $1895-1993$ on a $0.5^{\circ}$ latitude/longitude grid. Climate is represented at both monthly and daily timesteps. Variables are: precipitation, mininimum and maximum temperature, total incident solar radiation, daylight-period irradiance, vapor pressure, and daylight-period relative humidity. The dataset was derived from US Historical Climate Network (HCN), cooperative network, and snowpack telemetry (SNOTEL) monthly precipitation and mean minimum and maximum temperature station data. We employed techniques that rely on geostatistical and physical relationships to create the temporally and spatially complete dataset. We developed a local kriging prediction model to infill discontinuous and limited-length station records based on spatial autocorrelation structure of climate anomalies. A spatial interpolation model (PRISM) that accounts for physiographic controls was used to grid the infilled monthly station data. We implemented a stochastic weather generator (modified WGEN) to disaggregate the gridded monthly series to dailies. Radiation and humidity variables were estimated from the dailies using a physically-based empirical surface climate model (MTCLIM3). Derived datasets include a 100 yr model spin-up climate and a historical Palmer Drought Severity Index (PDSI) dataset. The VEMAP dataset exhibits statistically significant trends in temperature, precipitation, solar radiation, vapor pressure, and PDSI for US National Assessment regions. The historical climate and companion datasets are available online at data archive centers.
\end{abstract}

KEY WORDS: Climate dataset - Climate variability - Climate change - Ecosystem dynamics . Vegetation · Ecological modeling · VEMAP · Geostatistics · Palmer Drought Severity Index · PDSI 


\section{INTRODUCTION}

\subsection{Objectives}

Modeling biospheric responses to historical climate change and variability over the 20th century is crucial for validation of biogeochemistry and vegetation models against long-term observations and for understanding potential responses of ecosystems to future climate change. Such simulations require input of spatially and temporally complete, multivariate surface climate data that match this purpose (Cramer \& Fischer 1996). These data need to be at a spatial resolution that adequately captures key climatic gradients and of a long enough record to reflect important modes of temporal variation. However, even for the conterminous USA one of the best instrumented regions of the globesuch data are difficult to obtain. For example, temperature and precipitation station densities in the western USA prior to 1940 are insufficient for the interpolation of observations with confidence while accounting for physiographic effects such as large lakes and heterogeneous topography. Solar radiation and humidity observations are even more scattered, largely limited to airport sites with a bias to valley locations in mountainous regions. As a result, sophisticated techniques must be employed to construct extended time series of all variables at a sufficient spatial resolution throughout the domain, in a manner that (1) is consistent with physiography and vegetation (to the extent that vegetation is an expression of climate) and (2) maintains physical relationships among climate variables.

Our objective was to create a historical 'bioclimate' input dataset for the USA for simulation of time-dependent biogeochemical and biogeographical dynamics. This effort was part of an ecological model intercomparison study, the Vegetation/Ecosystem Modeling and Analysis Project (VEMAP), Phase 2. The overall requirement for the dataset was that it faithfully represents the 'bioclimate', i.e. those aspects of climate that control ecological processes. This goal is shared by other gridded historical climate datasets for regional to global domains, including Cooter et al. (2000), Thornton et al. (1997), and New et al. (2000). Specific requirements for the VEMAP2 dataset were that it be: (1) Spatially and temporally complete, with wallto-wall coverage spanning as much of the historical period as can be supported by the instrumental record; (2) temporally realistic, with accurate representation of climate variability at daily through decadal scales; (3) spatially realistic, reflecting topographic and other geographic controls over climate, and resolved sufficiently to capture key regional climate gradients and spatial patterns of temporal variability; (4) physically consistent across variables, in particular at the daily timestep; (5) multivariate, consisting of variables recognized as controlling ecological processes and commonly used as inputs to ecological models; (6) resolved at monthly and daily timesteps to match model input requirements, with the same climate represented at both scales.

\subsection{VEMAP and its common input datasets}

VEMAP was a multi-institutional, international effort addressing the response of ecosystem biogeography and biogeochemistry to variability in climate and other drivers in both space and time domains. Phase 1 (VEMAP1) compared a suite of biogeochemistry and biogeography models in their controls and equilibrium response to changing climate and elevated atmospheric carbon dioxide levels across the conterminous USA (VEMAP 1995, Schimel et al. 1997, Pan et al. 1998, Yates et al. 2000). Construction of a common input dataset, the VEMAP1 database, assured that differences in the model intercomparison arose only from differences among model algorithms and their implementation, rather than from differences in inputs (Kittel et al. 1995, 1996). The VEMAP1 database consists of long-term climatology (both monthly means and a characteristic daily climate), equilibrium climate change scenarios, soil properties, and potential natural vegetation.

Phase 2 (VEMAP2) evaluated time-dependent responses of a set of biogeochemical models and dynamic global vegetation models (DGVMs) to historical and projected transient climate and atmospheric $\mathrm{CO}_{2}$ forcings (Schimel et al. 2000, Gordon et al. 2004). The biogeochemistry models were TEM (Terrestrial Ecosystem Model; Tian et al. 1999), Biome-BGC (Biome-Biogeochemical Cycles Model; Thornton et al. 2002), Century (Parton et al. 1994), and GTEC (Global Terrestrial Ecosystem Carbon Model; Post et al. 1997), while the DGVMs were MC1 (MAPSS [Mapped Atmosphere-Plant-Soil System]-Century Coupled Model, Version 1; Daly et al. 2000) and LPJ (LundPotsdam-Jena Model; Sitch et al. 2003).

As in VEMAP1, a common database provided both (1) a 'level playing field' for intercomparison of models and (2) a faithful representation of the domain's bioclimate, permitting evaluation of historical simulations against observed ecological data - these features were critical to achieving VEMAP2 goals. In this paper, we describe the development of the historical climate dataset for the conterminous USA as a component of the VEMAP2 model input database. We also developed a companion set of future (21st century) transient climate change scenarios for the same domain derived from coupled atmosphere-ocean 
general circulation model (AOGCM) experiments (Kittel et al. 2000). We designed both the historical climate and transient climate change scenario sets to meet input requirements for this class of regional-global ecological models and as required by the experimental design of the VEMAP2 model intercomparison.

In the following sections, we present the overall design of the dataset (Section 2), techniques used to meet this design (Section 3), and derived datasetshistorical Palmer Drought Severity Index (PDSI) dataset and a model spin-up climate (Section 4). In Section 5, we describe spatial and temporal properties of the resulting dataset. We provide information regarding online access to the data and analysis and visualization tools (Section 6). Finally, we summarize key limitations and attributes of the dataset (Section 7).

\section{DATASET OVERVIEW}

\subsection{Spatial and temporal coverage}

The historical climate dataset was developed for the conterminous USA. The data are on a $0.5^{\circ}$ latitude $x$ $0.5^{\circ}$ longitude grid (Fig. 1), with cells bounded by $0.5^{\circ}$ latitude and longitude lines (as opposed to cells centered on $0.5^{\circ}$ intersections). The grid is the same used for VEMAP1 (Kittel et al. 1995, Rosenbloom \& Kittel 1996). The dataset covers a 99 yr period from 1895-1993. A companion historical climate dataset was developed for Alaska and adjacent portions of Canada covering 1922-1996; this set is also available online (Section 6) (Kittel et al. 2002). A follow-on product with updated, higher resolution historical monthly temperature and precipitation for the conterminous USA is presented in Gibson et al. (2002) and Daly et al. (2004).

\subsection{Timestep and variables}

Climate variables are given in 2 timesteps: daily values and monthly means (or monthly totals for precipitation). The dataset includes 7 surface climate variables: (1) and (2) minimum and maximum surface air temperature, (3) precipitation, (4) surface air vapor pressure, (5) surface air daylight-period mean relative humidity, (6) total incident solar radiation, and (7) daylight-period mean irradiance.

We included 2 humidity variables and 2 solar radiation variables because, while they represent the same climate information, different models require these inputs in different forms and their interconversion requires calculation at the daily level. Near-surface wind speed data are also required for some ecosystem models (e.g. in MC1 initialization) but are only available in the VEMAP database as long-term seasonal mean climatologies (Kittel et al. 1995; based on Elliott et al. 1986). While we did not determine daily (and monthly) wind speed for this dataset, its estimation from other daily variables has been explored by others

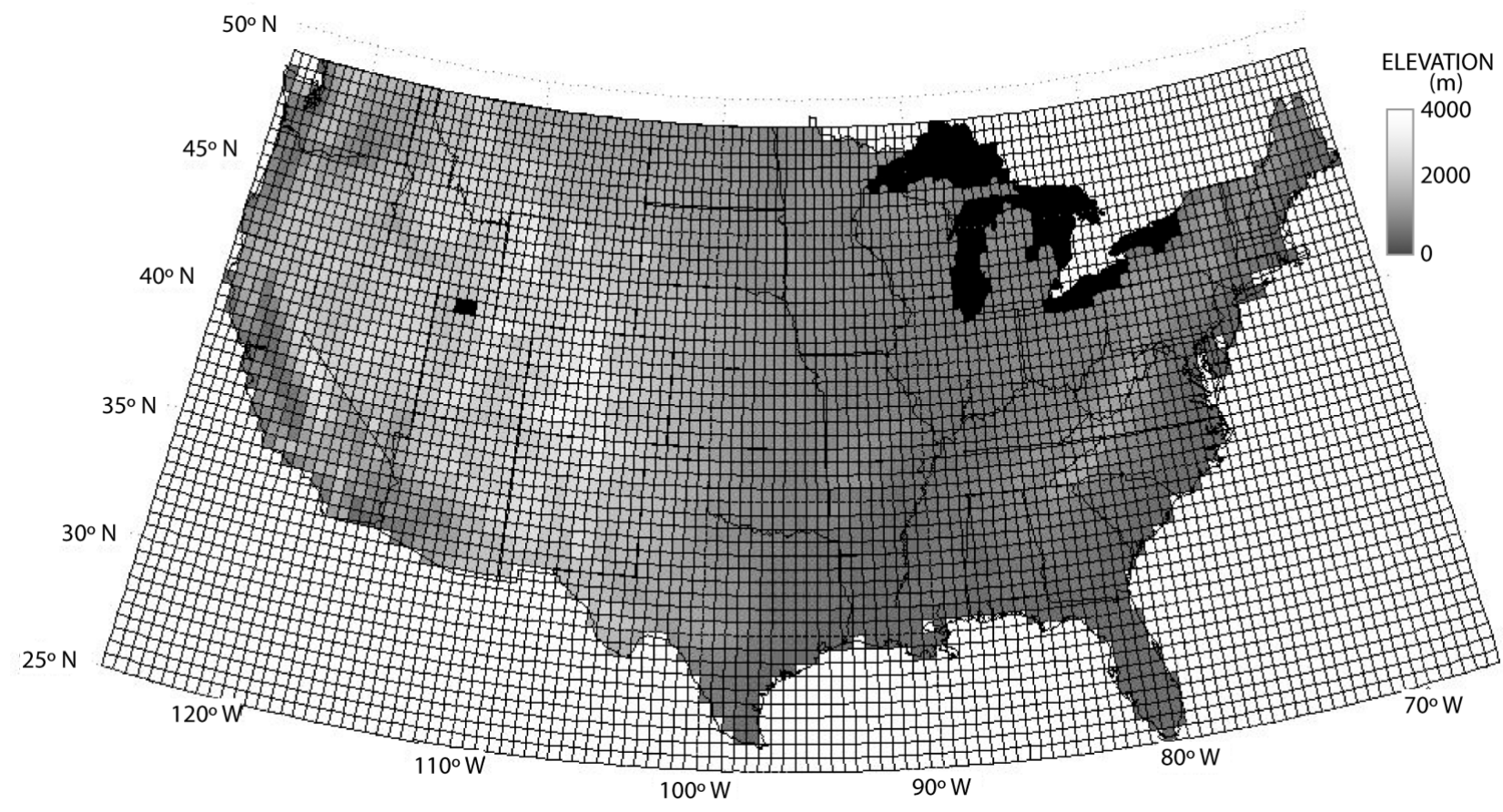

Fig. 1. Gridded domain for the conterminous US for the Vegetation/Ecosystem Modeling and Analysis Project, Phase 2 (VEMAP2) database. Background shows topography (m above sea level) 
(e.g. Hanson \& Johnson 1998, Parlange \& Katz 2000; see Section 3.3).

\subsection{Approach}

To create the historical gridded dataset, our approach was to:

Step 1 - Combine historical monthly and daily temperature and precipitation station datasets to create a unified set with the highest station density and most complete records that were readily achievable (described in Section 3.1).

Step 2 - Create temporally complete monthly minimum and maximum temperature and precipitation station records by modeling geostatistical relationships among stations with missing data and neighboring stations (Section 3.2.2).

Step 3 - Spatially interpolate these temporally complete monthly station records to the $0.5^{\circ}$ grid accounting for physical relationships between climate and physiography (Section 3.2.3).

Step 4 - Disaggregate monthly climate series to generate daily minimum and maximum temperature and precipitation using a stochastic weather generator (Section 3.3).

Step 5 - Empirically estimate daily (and monthly) solar radiation and humidity variables from daily temperature and precipitation series, while maintaining physical relationships among these variables (Section 3.4).

\section{DATASET DEVELOPMENT}

\subsection{Step 1. Temperature and precipitation data}

For the conterminous USA, we obtained monthly mean minimum and maximum temperature records for 5476 stations and monthly precipitation records for 8514 stations (Fig. 2a). These data were compiled from the National Climatic Data Center (NCDC) Historical Climate Network (HCN) database (Easterling et al. 1996; Fig. 2b), other primary and cooperative network datasets (NCDC undated a, 1994a,b), and Natural Resources Conservation Service (NRCS) SNOTEL (snowpack telemetry) data (NRCS 1996; Fig. 2c). While HCN data provided the longest and most homogeneous records, inclusion of additional data sources allowed interpolation of spatial and temporal climate patterns over regions with high spatial heterogeneity in factors controlling climate. In particular, inclusion of SNOTEL sites significantly improved station density in mountainous regions of the western USA (Fig. 2c). We also used daily minimum and maximum temperature and precipitation data from 526 stations to parameter- ize the stochastic daily weather generator (Step 4, Section 3.3). Sources for daily data included $\mathrm{HCN}$ and other first order and cooperative network daily datasets (NCDC undated b,c, Easterling et al. 1999).

We used data starting in 1895 (prior to this, precipitation stations numbered $<600$, i.e. average densities $<0.2$ stations per grid cell) and through 1993 (last complete year in the HCN set available at the time the set was surveyed). Data quality checks included tests (1) that temperature minimum values did not exceed corresponding maxima, (2) for nonsense precipitation values (e.g. less than zero), and (3) for nonsense metadata (such as obvious errors in latitude, longitude, and elevation, e.g. from double conversion of feet to meters).

The HCN precipitation and temperature dataset consists of stations selected to have long-term, relatively complete records which were adjusted for timeof-observation differences, instrument changes and moves, station relocations, and urbanization effects (Easterling et al. 1996). HCN processing also included infilling of missing data based on neighboring stations. The high level of quality checking and attention to station histories in monthly HCN data, along with extensive coverage across the domain in the earlier part of the record, provided a strong basis for reliance on this set for spatial interpolation of monthly regional temperature and precipitation anomalies (Step 2, Section 3.2.2). This was key for creating a gridded historical dataset extending back to the end of the 19th century. However, there are important record inhomogeneities and other time-dependent biases that are neither accounted for in the other data sources, nor completely in the HCN. In addition, local anomaly patterns are likely to be less well represented in the earlier part of the record because of the lower density of $\mathrm{HCN}$ and other long-term stations. These limitations must be kept in mind when evaluating and using the VEMAP2 gridded historical climate dataset. The primary purpose of the dataset is to provide the best representation of climate patterns in space and time for simulating ecological processes. To this end, the goal of data completeness in space and time was weighted more heavily than an alternate objective of including only the highest quality and longest term station records such as would be needed for a rigorous assessment of climate trends and variability.

\subsection{Steps 2 and 3. Spatial interpolation}

\subsubsection{Approach}

As introduced, a key issue in the development of gridded time series of climate data is spatial interpolation of station data in physiographically heterogeneous 
terrain. This is especially difficult in the early part of the historical record when the density of stations with long-term records is low (Fig. 2b, 3). To solve this problem, we chose to separate interpolation of existing station data to the grid into 2 spatial statistical modeling processes: a climate anomaly component and a physiographically forced component.

In the first process, we assumed that climate variability is dominated by regional forcing and that this forcing can be represented by anomaly patterns. The use of anomalies removed the mean field, which is strongly determined by physiographic factors, revealing spatially coherent climate variability patterns. We modeled this spatial autocorrelation structure with geostatistical techniques. The resulting spatial prediction model was used to interpolate climate anomalies to locations where station data were missing (Step 2, Section 3.2.2). The result of this process was reconstruction of station records that were discontinuous or limited in length, creating complete records for the period 1895-1993.

The second spatial process was interpolation of these reconstructed station records to the grid using a model accounting for physiographic effects (Step 3, Section 3.2.3). We employed a knowledgebased system that uses our understanding of how topography and other physiographic factors influence the spatial distribution of temperature and precipitation. The output of this process was an 1895-1993 time series of $0.5^{\circ}$ gridded monthly temperature and precipitation.

3.2.2. Step 2. Statistical reconstruction of station records - kriging prediction model

Geostatistical model. To create complete precipitation and temperature station records, we used a local (moving window) kriging prediction method following Haas $(1990,1995)$. To impute monthly anomalies wherever a station value was missing, this method takes advantage of the observation that temperature and precipitation anomalies tend to be regional in scope. In the moving window approach, we first modeled regional spatial autocorrelation structure on the order of $1000 \mathrm{~km}$ from the site
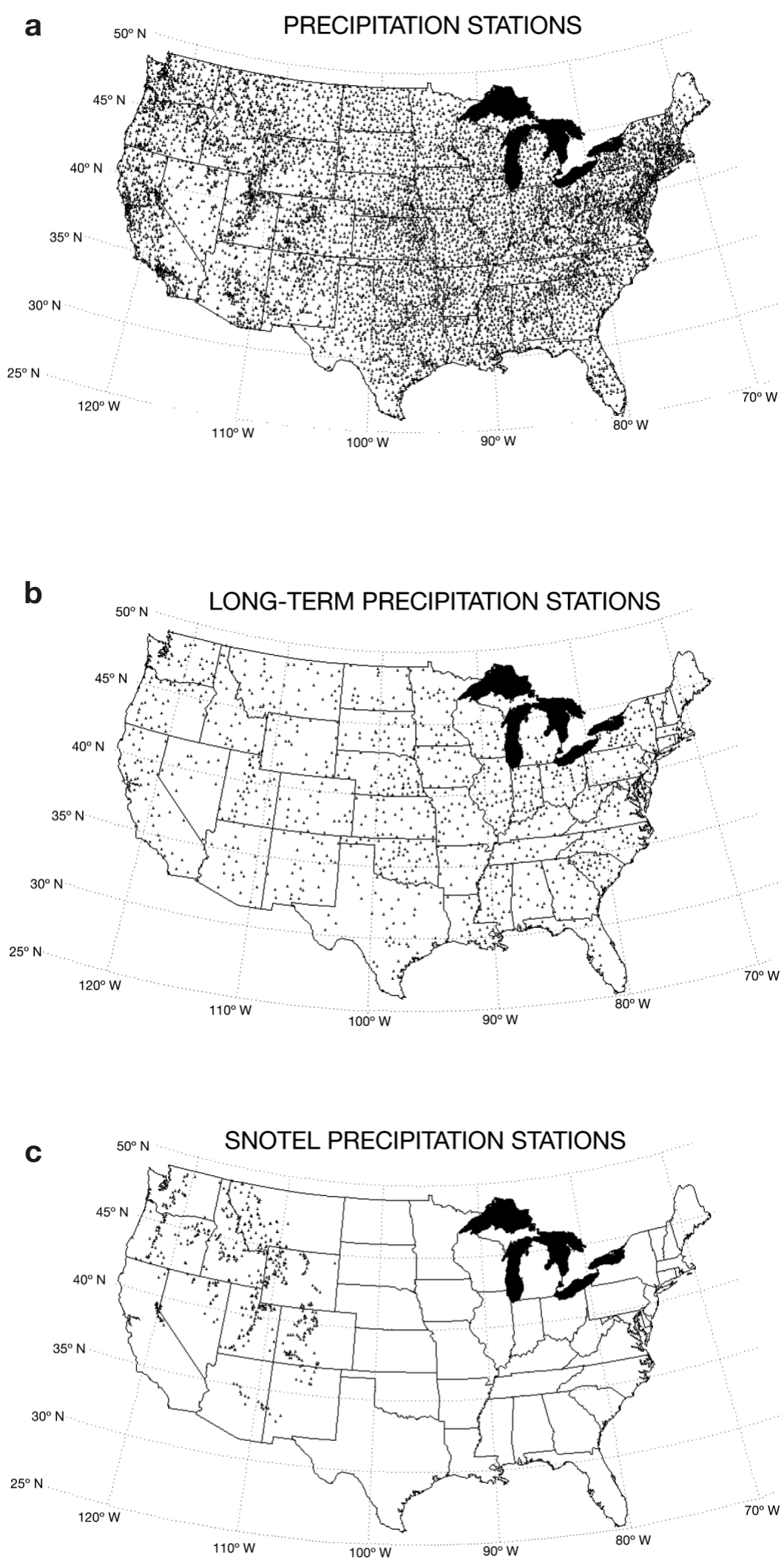

Fig. 2. (a) Precipitation stations used to develop the historical precipitation dataset, (b) long-term precipitation stations, primarily Historical Climate Network (HCN) stations, (c) snowpack telemetry (SNOTEL) stations 


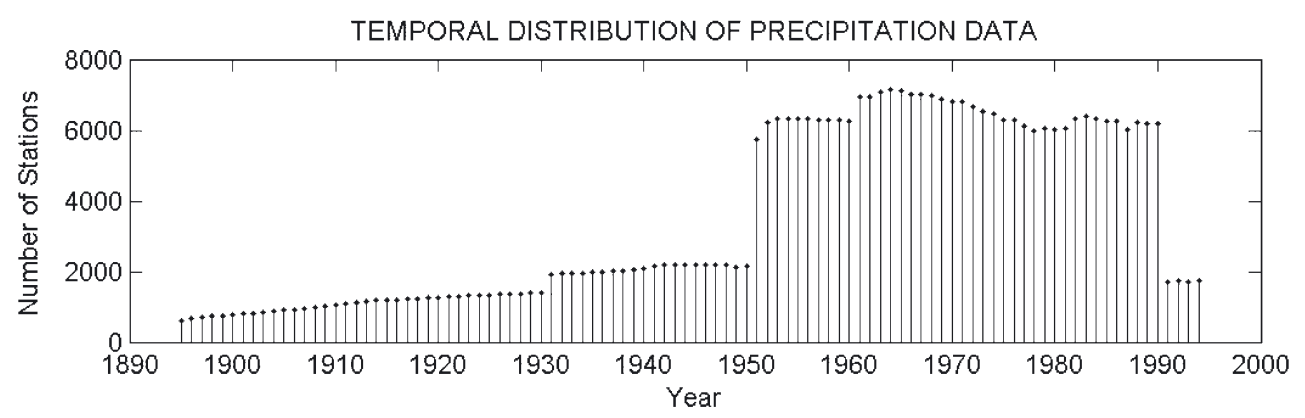

Fig. 3. Number of precipitation stations with data as a function of year. Drop after 1990 reflects the end of monthly time series data in NCDC (1994a); data after that were from the HCN dataset (Easterling et al. 1996)

to be predicted using 200 neighboring stations (Fig. 4); actual window size varied based on station density. The use of a local, moving window assumed that spatial structure was locally uniform, but allowed for the spatial correlation function to vary by region (e.g. Fig. $4 \mathrm{~b}$ vs. d). The correlograms were used to build the kriging prediction model.

We applied the kriging model to estimate a missing value using the 10 closest sites with data available at the time point to be predicted. Using a limited number of predictor sites was appropriate both computationally, because it greatly reduced the size of the system of linear equations that must be solved for each prediction, and theoretically, because it kept the prediction area close to the predicted site when possible. A thinplate spline prediction model was also tested; its crossvalidation prediction errors were higher than for the local kriging model.
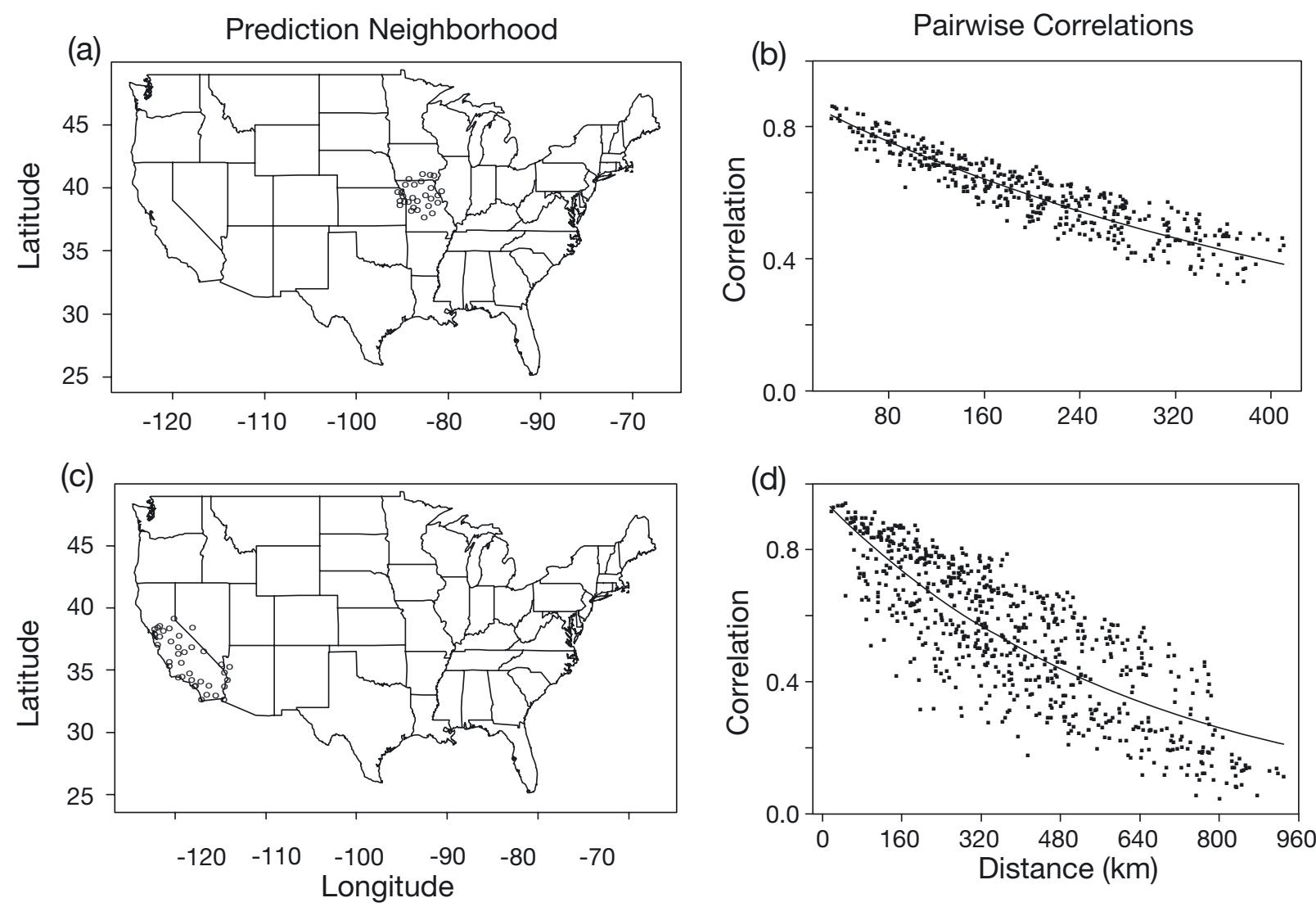

Fig. 4. Spatial autocorrelation structure in monthly precipitation anomalies for $(a, b)$ a site in the Midwest where autocorrelation was strong, (c, d) a site in southern California where it was weak. (a, c) Maps show a site and its neighborhood ('local window') of 20 stations used to develop site correlograms shown in (b, d). Site correlograms show correlations among all station pairs as a function of distance (dots) and best fit line with an exponential model. In production runs, the kriging prediction model used 200 stations to model the correlation function (Section 3.2.2) 
Method details. HCN station data flagged as infilled (primarily in the temperature dataset) were first deleted so that a consistent process would be used throughout for infilling missing values (time of observation, station change, and other adjustments were retained). Monthly minimum and maximum temperatures were converted to monthly mean temperature and mean diurnal temperature range to create 2 variables that were roughly independent (Royle 2000). This allowed us to avoid analyzing 2 largely redundant fields and to ensure instead that the analysis would emphasize important differences between them. Precipitation data were square-root transformed to normalize their distribution and make site variances more homogeneous. Monthly anomalies for converted temperature variables and transformed precipitation were calculated relative to corresponding long-term monthly means.

Univariate local kriging was used for precipitation and bivariate methodology (co-kriging; Cressie 1993a) was implemented for mean temperature and temperature range anomalies. The prediction neighborhood of 10 nearest stations was selected at each timestep. Larger neighborhoods (up to 25 stations) were considered, but with little increase in precision. The entire period of overlap in data (from all months, all years) among selected stations and the site of prediction was used to construct a kriging model for a given missing month. Spatial covariance structure was assumed to be isotropic within a window, i.e. similar in structure in all directions in space. Unlike Haas (1995), we did not allow spatial functions to vary with time, i.e. by season or year. However, kriging was based on correlograms, with spatial covariances standardized by station monthly variances, which reduced seasonal dependence in spatial structure. Isotropy and interannual stationarity were important assumptions that made the model numerically more tractable and better supported by the amount of data available, but which did not account for potentially important spatio-temporal features of climate variability. These features include anisotropy within windows arising from non-homogeneous forcing of climatic variability by terrain (Diaz \& Bradley 1997, Kittel et al. 2002) and decadal continental circulation changes that alter regional relationships in climate anomaly patterns (Trenberth \& Hurrell 1994).

Model evaluation. The kriging process produced realistic full-period time series for stations with partial records (Fig. 5), with the reconstructed records having interannual variability patterns consistent with neighboring stations. Prediction error was evaluated using cross-validation, where the model predicted station data that had been withheld from the analysis. In a cross-validation analysis using 100 sites, predicted values closely estimated observed values with correlation coefficients ranging from 0.72 to 0.96 (Fig. 6a). Sites in the Central Lowlands and Pacific coastal states tended to have stronger correlations ( $r>0.90)$, while areas in the western mountains and Great Lakes states tended to have the lowest correlations $(r \leq 0.80)$. This pattern indicates that generally lower errors occurred in regions with relatively low climatic heterogeneity and/or high station densities, as would be expected. Magnitude of errors was generally small relative to interannual variability. Quantile analysis of precipitation cross-validation errors showed a tendency for underprediction of the highest values and overprediction of lowest values, so that there was a slight reduction in variance in predicted time series.

Cross-validation errors for temperature and precipitation were higher in the early vs. latter part of the record due to lower station densities (Fig. 6b). On average, precipitation cross-validation errors roughly doubled going from recent decades back to the early part of the record (mean squared error, MSE $=1.3$ to $2.5 \mathrm{~mm} \mathrm{mo}^{-1}$; Fig. 6b). This doubling corresponded to an order of magnitude decrease in station numbers across the domain ( 7000 to $\sim 800$ stations, with corresponding change in average densities of 2.1 to 0.2 stations per grid cell; Fig. 3). This proportionally low response of errors to station density suggests that the network of long-term, primarily $\mathrm{HCN}$, precipitation stations captured major variability patterns across the conterminous USA.

Interannual variability was artificially reduced during the first part of reconstructed records for areas

RECONSTRUCTED STATION PRECIPITATION RECORDS
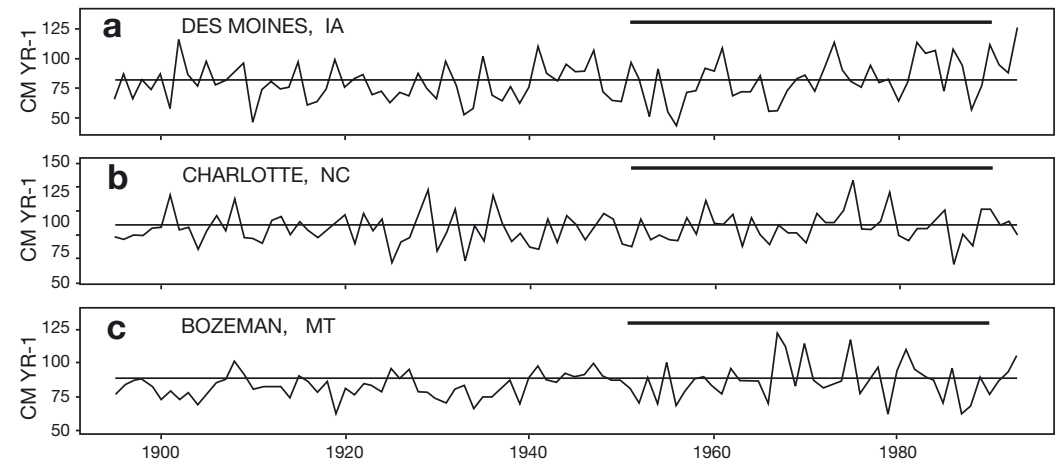

Fig. 5. Precipitation $\left(\mathrm{cm} \mathrm{yr}^{-1}\right)$ records for stations in different climatic regions, as in-filled with the kriging prediction model: (a) Des Moines, Iowa; (b) Charlotte, North Carolina; (c) Bozeman, Montana. Horizontal line through the time series is the $40 \mathrm{yr}(1951-1990)$ station mean, including reconstructed data. Horizontal bar in upper right spans the period when observed data were available 


\section{CROSS-VALIDATION}

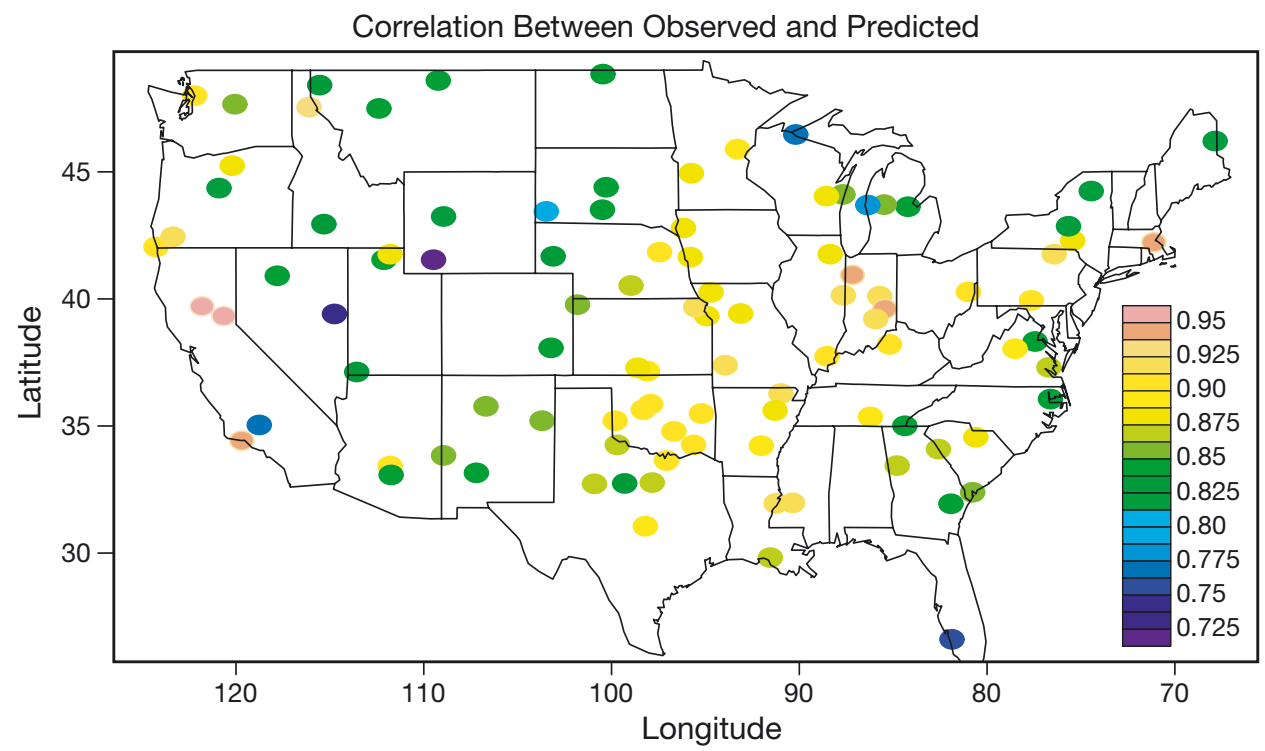

b

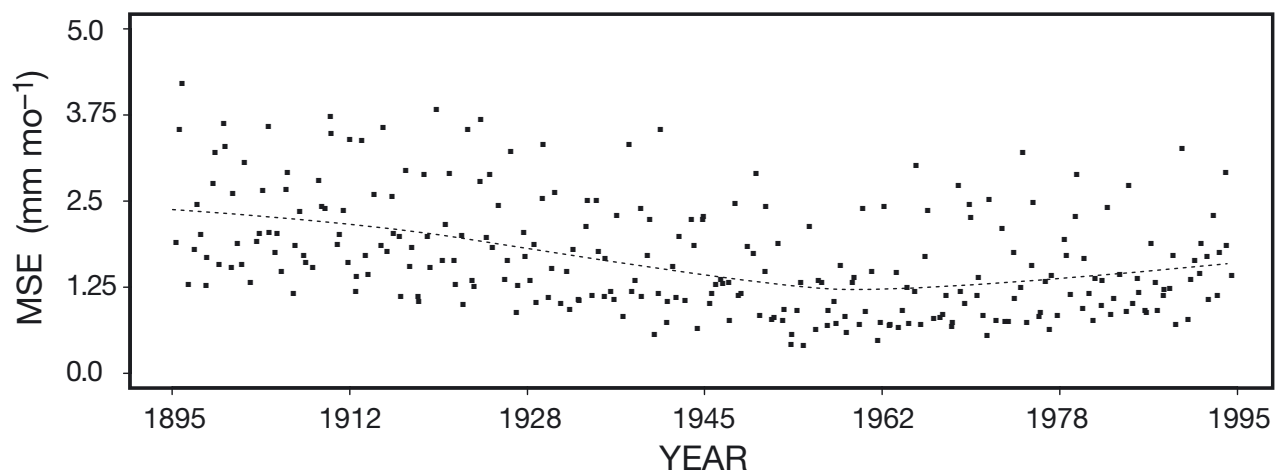

Fig. 6. Kriging model crossvalidation. (a) Correlation coefficients between observed and predicted precipitation for 100 cross-validation sites. (b) Time dependence in crossvalidation errors for precipitation, expressed as mean squared error (MSE) for square-root transformed precipitation. Dots are monthly MSE averaged across 100 cross-validation sites (units = $\mathrm{mm} \mathrm{mo}^{-1}$ ). Dotted line is a smoothing spline fit of MSE values where station densities were low early on, as in the mountain and intermountain west (e.g. Fig. 5c). This was not an issue in regions where stations densities were high for most of the record (e.g. Fig. 5a,b). This effect is conceptually consistent with limitations of the kriging model we implemented and is a consequence of the model generating overly smoothed spatial fields when there are too few station observations to capture regional structure in variability patterns (Cressie 1993b). As station density is reduced, the model reaches further away from a site to find predictor stations and blends unrelated anomaly patterns from adjacent regions to predict missing station data. Poorly related anomalies tend to cancel each other when they are blended, diminishing overall variance in reconstructed time series. This variance reduction is an artifact of the model, as evident from the observation that such shifts generally coincide with a dramatic change in station density (Fig. 3) and are neither seen in long-term observed station records, nor in reconstructed records where densities remain high. Follow-on analyses demonstrated that ensemble predictions generated stochastically using modelestimated errors can adequately generate this 'missing' variance (Fuentes et al. 2004).

\subsubsection{Step 3. Spatial interpolation with physiographic adjustment - PRISM}

We used PRISM (Parameter-Elevation Regression on Independent Slopes Model; Daly et al. 1994, 2001, 2002 ) to spatially interpolate temporally complete station records from Step 2 to the $0.5^{\circ}$ grid. PRISM is an interpolation system that uses a spatial-climate knowledge base to parameterize and configure a weighted climate-elevation regression function. The weighted regression function is applied to each grid cell in a moving window fashion; the size of this window depends on terrain complexity and station density. At each grid cell, the model assigns weights to nearby stations, based on their perceived climatic similarity 
to the cell. Factors accounted for were: (1) Distance: station regression weight decreases with distance from the grid cell. (2) Elevation: weight decreases with increasing elevation difference. (3) Topographic facet: weight is greatest for stations with similar slope and aspect as the cell, as determined at several spatial scales. (4) Orographic effectiveness of terrain: weight is greatest for stations in terrain that has a similar ability to enhance precipitation as estimated by steepness. (5) Coastal proximity: weight is greatest for stations with similar distance and exposure to a large water body (e.g. lake, ocean). (6) Atmospheric inversion: weight is greatest if a station and the cell are either both affected by mesoscale boundary layer processes (e.g. in a valley located below the top of an inversion), or both more strongly influenced by the free atmosphere (e.g. on ridgetops above an inversion); this allows for a different climate-elevation regression within each layer (for both temperature and precipitation) if an inversion is supported by the data (Daly \& Johnson 1999). (7) Clustering of stations: highly clustered stations are assigned lower weights to minimize spatial over-representation.

PRISM was applied independently for each month of the 99 yr record. Station values were quality checked before processing. PRISM processing was done on a

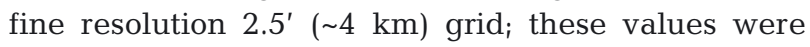
aggregated to the VEMAP $0.5^{\circ}$ grid using a modified Gaussian filter (after Barnes 1964). Post-processing checks included visual inspection of monthly gridded maps for extreme outliers.

\subsection{Step 4. Stochastic generation of daily tempera- ture and precipitation - WGEN}

We used a daily weather generator, a modified version of WGEN (Richardson 1981, Katz 1996, Mearns et al. 1996, Parlange \& Katz 2000), to statistically disaggregate monthly temperature and precipitation values to a daily time series for the 1895-1993 period. WGEN uses a first-order Markov chain model to predict occurrence of precipitation (wet vs. dry days) based on whether the previous day was wet or not; this allows for the persistence of wet and dry days. WGEN then stochastically predicts precipitation event size (assuming a gamma distribution) and daily minimum and maximum temperatures. Temperature prediction is based on daily temperature means and variances being conditional on whether a day is wet vs. dry. This permitted reduced diurnal temperature range on wet days, maintaining physical relationships between daily precipitation and temperature. In this model version, all parameters were allowed to vary by location, determined from station data (Katz 1996). We did not use the modified WGEN's capabilities for stochastic simulation of daily solar radiation, humidity, and near-surface wind speed because of the inadequate number of parameterization stations with daily observations of these variables, especially in mountain regions (Parlange \& Katz 2000). We further modified WGEN to include separate parameterizations for wet vs. dry years. Such conditional parameterization better represents daily precipitation variance structure, because precipitation event statistics shift under drought vs. wet-period conditions (Wilks 1989).

Parameterization of WGEN was based on daily records from $526 \mathrm{HCN}$ and cooperative network stations (Section 3.1) for the period 1930-1989. This parameterization period was selected based on data availability and to span several drought and wet periods in the 20th century for most regions. Additional selection criteria and quality checks on these data were: (1) Station records had to exist for at least $90 \%$ (54 yr) of the $60 \mathrm{yr}$ period and had to have at least 5 out of the first $10 \mathrm{yr}$ of the period (this was to ensure that the 1930s drought period in the western and central USA was represented). (2) We allowed up to $3 \mathrm{~d}$ $\mathrm{mo}^{-1}$ of missing precipitation data and $5 \mathrm{~d} \mathrm{mo}^{-1}$ of missing temperature data for a month to be considered complete. (3) All 3 variables (precipitation and maximum and minimum temperature) had to be present in a station record. (4) If recorded precipitation amounts were accumulated over $>24 \mathrm{~h}$, then the observation was eliminated; trace amounts were treated as zero.

We ran WGEN for each grid cell for the $99 \mathrm{yr}$ record; model outputs are illustrated in Fig. 7a. Parameterizations were assigned to cells based on nearest daily station to cell centers; a given parameterization was applied on average to 6 cells. WGEN simulations were constrained by gridded monthly values of temperature and precipitation (from Step 3). Because this constraint was not strictly met within WGEN (due to the stochastic nature of the model), we forced a match between daily and monthly climates. For each cell, we created ensembles of daily series for each year in the record. From these we selected monthly daily series whose monthly statistics best matched the gridded monthly values. Daily values of the selected months were nudged so that monthly statistics of the daily series exactly matched the monthly data. WGEN was run separately for each cell with no coordination in the generation of series among adjacent cells. The lack of daily spatial coherence restricts the utility of the dataset to application models, such as those in VEMAP, with no cell-to-cell interaction on a daily timestep (see Section 7.1). Because the daily generation process is stochastic, the timing of key events for a given year (e.g. date of last and first frost) and date- 
a GENERATED DAILY WEATHER-MISSOULA, MT

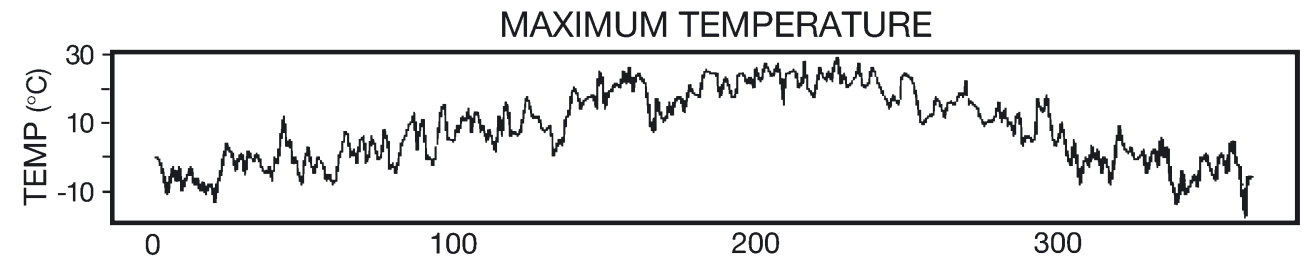

MINIMUM TEMPERATURE
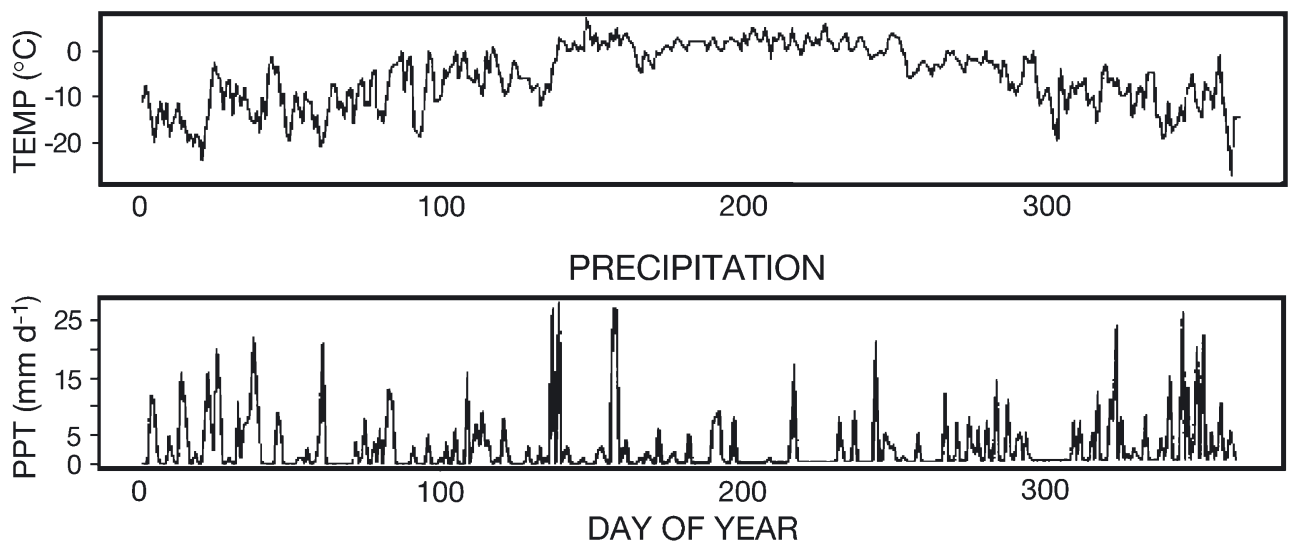

b
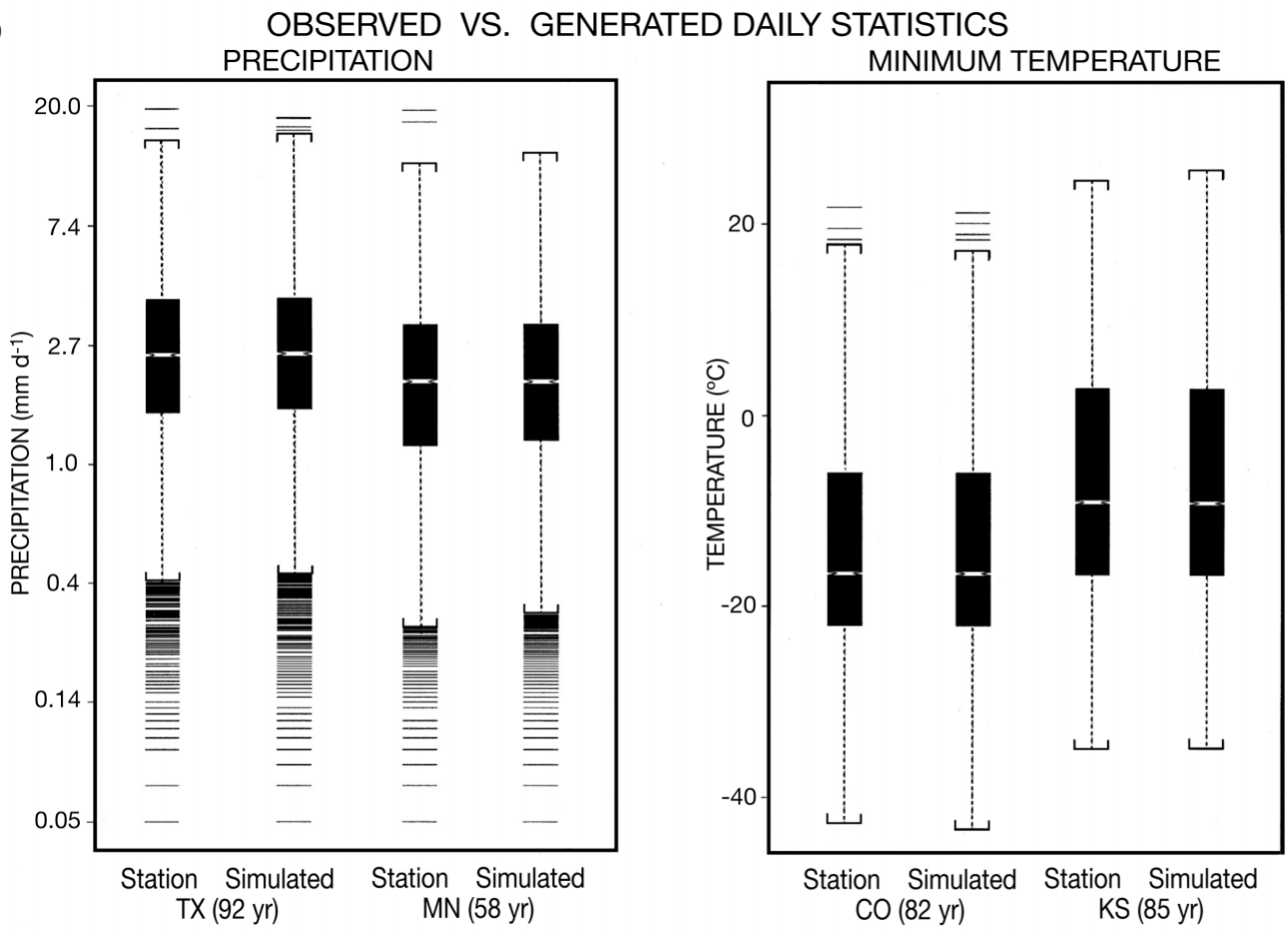

Fig. 7. (a) Generated daily climate from WGEN showing temporal autocorrelation (e.g. persistence of wet and dry days) and crosscorrelation structure of maximum and minimum temperature and precipitation. Output is for a characteristic year for the grid cell for Missoula, Montana, from the VEMAP1 dataset (Kittel et al. 1995) and reflects behavior of the 99 yr VEMAP2 daily dataset. (b) Comparison of daily frequency distributions for station observations vs. corresponding grid cell's WGEN-simulated record for January precipitation or minimum temperature, for selected point in TX. TX: central Texas; MN: southern Minnesota; CO: western Colorado; KS: northwestern Kansas. Notch plots show median (center of notch), SD (white area = 2 SD), interquartile range (IQR; dark boxes around median, spanning 25 to $75 \%$ of values), data range (brackets), and outliers (bars beyond the brackets; defined as values $>1.5$ IQR). 'Station' notch plots are for daily observations from a long-term station (usually a daily HCN site), and 'simulated' plots are VEMAP2-generated dailies. Precipitation plot $y$-axes are in [ $\ln \left(\right.$ precipitation)] space (units $=\mathrm{mm} \mathrm{mo}^{-1}$ ). The comparison covered the full length of a station's record (period length in years is given at the base of each plot) 
sensitive statistics (such as growing-degree days) will not precisely match those in the observed daily record.

We evaluated this process by comparing the frequency distributions of observed (station) vs. generated daily records for 10 locations that represented different climate regimes across the domain. The generated series was created using parameterizations and monthly values from the corresponding grid cell. For all sites, the observed vs. generated frequency distributions matched closely (e.g. Fig. 7b). Most critically for precipitation, the frequency and magnitude of both high and low extreme events were well captured-a record detail that might be expected to be lost in the simplification of daily processes in a statistical model (Fig. 7b).

The process of disaggregating monthly records to generate daily series differed from approaches used in other datasets where observed daily records were spatially interpolated or assigned to a neighborhood of grid cells (Thornton et al. 1997, Eischeid et al. 2000, Cooter et al. 2000). These techniques have the advantage of providing spatial coherence in daily series and of closely reflecting the observed daily record (so that date-sensitive historical information is retained). Disaggregation was more appropriate for the VEMAP2 dataset because of the need to represent daily climate over highly heterogeneous terrain early in the 20th century, when daily station densities were low. We assumed that, under these conditions, it was more reasonable to spatially distribute dailystructure parameterizations than actual daily series. In methods that grid daily observations, incongruities arise when station densities are very low, because cell records will be assigned or interpolated from stations at a great distance from the cell. The likely result is that a cell's daily series may reflect that of a markedly different climate regime, with, for example, different daily frequency and autocorrelation structure and/or a different seasonal pattern of temperature and precipitation.

On the other hand, in the approach of assigning parameterizations to cells as used here, a cell's generated daily series was based on a parameterization throughout the record from the same nearby station which was likely to closely approximate the appropriate daily climate regime for that cell. This was possible because parameterizations were based on a long (60 yr) portion of the record when daily station densities were greater than in the early record. Our approach of assigning parameterizations to a cell from the nearest station, however, does not account for the possibility of sharp climate regime changes in the vicinity of a cell. This could have led to a cell's parameterization coming from a station, for example, on the other side of a major mountain divide. In future efforts, this could be controlled for by pairing cells with stations based not only on proximity (as was done here), but also on other common factors that reflect climate regime, such as those accounted for in PRISM, e.g. topographic facet (Daly et al. 2002; see Section 3.2.3).

\subsection{Step 5. Estimation of solar radiation and humidity - MTCLIM3}

We used a physically-based empirical surface climate model, MTCLIM3 (Thornton et al. 1997, 2000, Running et al. 1987), to estimate daily records of total incident solar radiation (SR), daylight-period irradiance, vapor pressure (VP), and daylight-period relative humidity from daily minimum and maximum temperature and precipitation. This approach maintained physical relationships among these surface climate variables on a daily and monthly basis. MTCLIM3 determines daily SR, based on potential solar inputs (as a function of latitude and year date), and transmittance estimated from diurnal temperature range, $\mathrm{VP}$, and occurrence of precipitation, as well as elevation and solar beam geometry (Bristow \& Campbell 1984, Thornton \& Running 1999). The model estimates daily VP based on a minimum temperature (as a first approximation of dew point temperature) and evaporative demand based on SR inputs (Kimball et al. 1997). As VP and SR are inputs in each other's calculation, MTCLIM3 iteratively solves for these variables. Mean daily irradiance was calculated from SR and day length. Relative humidity was calculated from VP using a mean daylight-period temperature (Running et al. 1987). Monthly means of radiation and humidity were derived from daily values.

Kimball et al. (1997) and Thornton \& Running (1999) evaluated the performance of MTCLIM3 at the site level under different climate regimes. Across the VEMAP domain, MTCLIM3-generated VP fields reflect the broad regional patterns in Marks's gridded VP climatology (Marks 1990, Marks \& Dozier 1992), which was interpolated from weather station data with topographic adjustment (Fig. 8a,b). MTCLIM3-estimated SR gridded climatologies compared well with monthly gridded SR climatologies we developed from the Solar and Meteorological Surface Observation Network (SAMSON) dataset (NREL 1993) (Fig. 8c,d). For this comparison, we calculated 20 yr monthly mean SR from 210 SAMSON station time series, which represent modeled as well as observed values. Station means were gridded using kriging with elevation as an independent pre- 

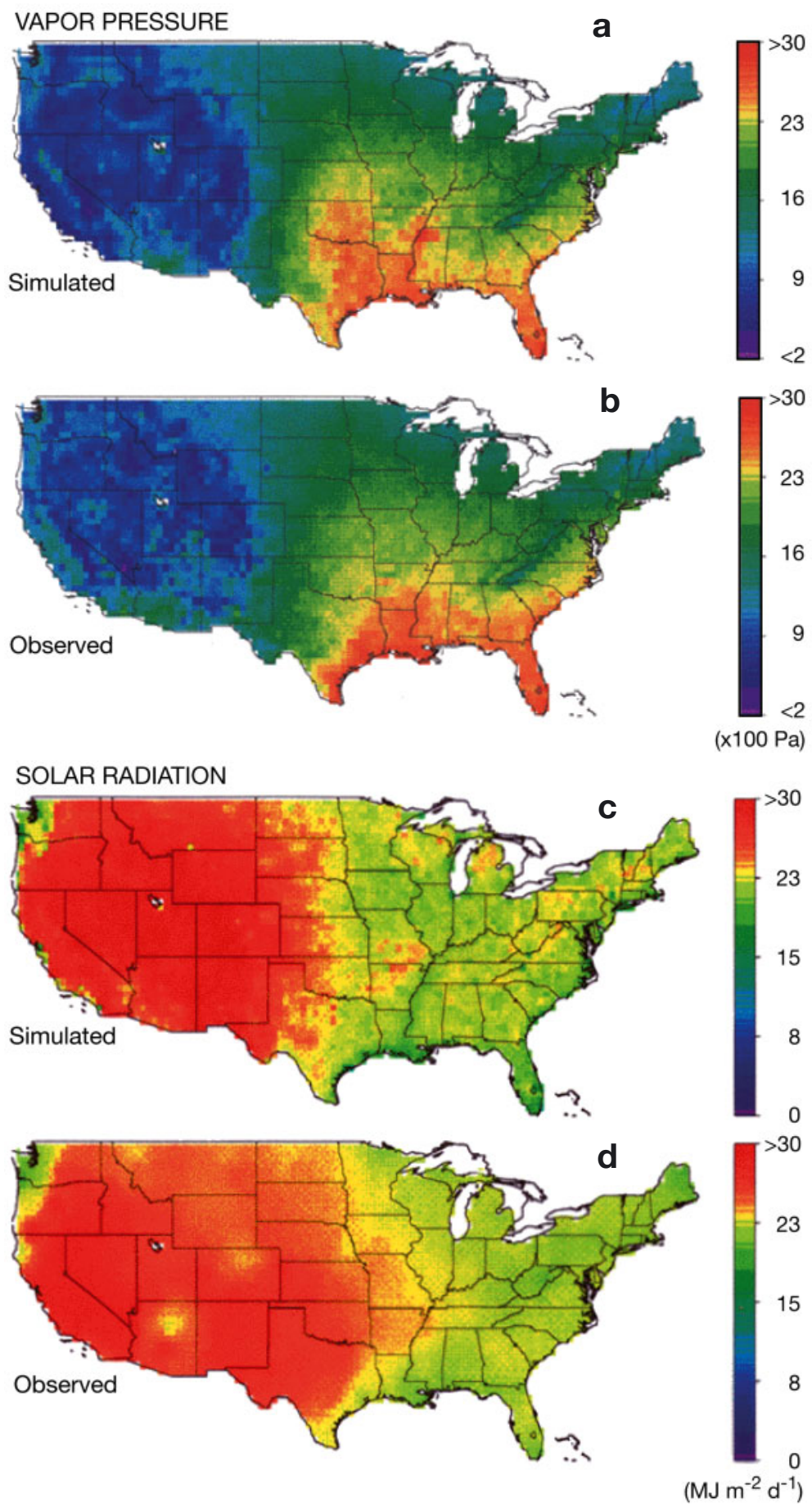

Fig 8. MTCLIM3 simulated vs. observed vapor pressure (VP) and total incident solar radiation (SR) climatologies. July mean VP (100 Pa) from (a) MTCLIM3 and (b) Marks (1990), regridded to the VEMAP grid (note that reds represent high VP and blues low values). July mean SR ( $\mathrm{MJ} \mathrm{m}^{-2} \mathrm{~d}^{-1}$ ) from (c) MTCLIM3 and (d) SAMSON station data (NREL 1993) gridded using kriging with elevation as an independent predictor variable; differences in map texture result from low SAMSON station densities in (d). MTCLIM3 values $(\mathrm{a}, \mathrm{c})$ were simulated using VEMAP1 characteristic-year temperature and precipitation dailies whose monthly statistics match corresponding long-term means (Kittel et al 1995). These map comparisons are limited in part by uncertainty in observed fields $(b, d)$ arising from the low density of stations reporting humidity and SR and from their spatial interpolation while accounting for elevation (Section 3.4) dictor variable to empirically account for this control (Fig. 8d). While broad spatial patterns generated by MTCLIM3 were confirmed by comparisons with gridded SAMSON climatologies, this evaluation is limited, because (1) much of the SAMSON data are simulated (with detailed site-level models) and (2) a subset of these data (from stations dominated by observed values) was used to parameterize MTCLIM3.

\section{Derived Datasets}

\subsection{Palmer Drought Severity Index (PDSI)}

PDSI indicates the relative status of soil moisture supply and is based on a water balance concept that provides a standardized measure of moisture conditions, typically on a monthly basis (Palmer 1965, Alley 1984). We calculated historical monthly PDSI based on VEMAP2 historic monthly precipitation and temperature data following Alley (1984); required soil information was also from Alley (1984). PDSI is a normalized, unitless value that varies roughly between -6.0 (severe dry) and +6.0 (extremely wet), where -0.5 to +0.5 is near normal. It is a common metric for determining when a dry or a wet spell begins and ends. PDSI is a meteorological index because it integrates the effects of both precipitation and temperature (through its control over evaporative demand) on surface water balance. PDSI, however, does not account for other potential hydrological processes and inputs such as runoff routing. Key to PDSI is that it has a persistence component, keeping track of prior soil moisture conditions. For example, an abnormally wet month in the middle of a long-term dry period should not have a major impact on the index, nor would a series of months with near-normal precipitation following a serious drought indicate that the drought is over.

\subsection{Detrended model spin-up climate-} TSPIN

Most ecological models that simulate longterm dynamics of biogeochemical pools (e.g. soil carbon) and vegetation structure 
require a spin-up run to initialize these state variables. To provide the input for such runs, we created a climate series for each grid cell with the following features: (1) The spin-up series has no long-term trend, so that it can be looped through as many times as required for a model spin-up run with no discontinuity at the point where the series is repeated. (2) The series retains interannual and decadal variability characteristics of the historical series. This feature is required for spin-up runs because variability at these time scales has an important effect on biogeochemical and vegetation dynamics. (3) The long-term mean of the spin-up series matches the mean climate of the beginning of the historical series, so that there is no discontinuity at the transition from the spin-up to the historical period. We created a $100 \mathrm{yr}$ monthly and daily spin-up climate (TSPIN) as follows, for each grid cell:

Detrending. Long-term trends in the monthly historical minimum and maximum temperature and precipitation grid cell time series were removed by passing these series through a 30 yr running average high-pass filter. To create a 100 yr series, an additional year was added to the 99 yr records by repeating Year 2 at the start of the record (Year 0 value $x_{t 0}=x_{t 2}$ ).

Long-term mean adjustment. The longterm mean of the detrended climate series was adjusted to match the corresponding mean for the first $15 \mathrm{yr}$ of the historical record (1895-1909).

Dailies and additional variables. We then used the same processes implemented in the development of the historical dataset to generate daily records (Step 4) and radiation and humidity variables (Step 5) (Sections 3.3 and 3.4).

\section{RESULTS}

\subsection{Space and time slices}

The dataset reflects both broad latitudinal and longitudinal patterns of climate, as well as finer-scale physiographic effects such as seen across the mountainous west (Fig. 9). The data capture continental-scale temporal variability patterns including droughts of the 1930s and 1950s and the increasing trend to moister conditions from the late 1950s into the early 1980s (Fig. 10a). The dataset illustrates contrasting regional patterns and their temporal progression, as seen during the mid-1950s, when the Pacific Northwest (i.e. NW USA) had above or near-normal precipitation, while much of the central USA sustained a major drought (see time series in Fig. 9a) that broke in 1957 (Fig. 9b). Contrasting regional patterns of cold vs. warm periods are also represented (Fig. 11). A time-longitude section of August PDSI shows how droughts in the central and far western USA in the 1920s merged and intensified in the 1930s
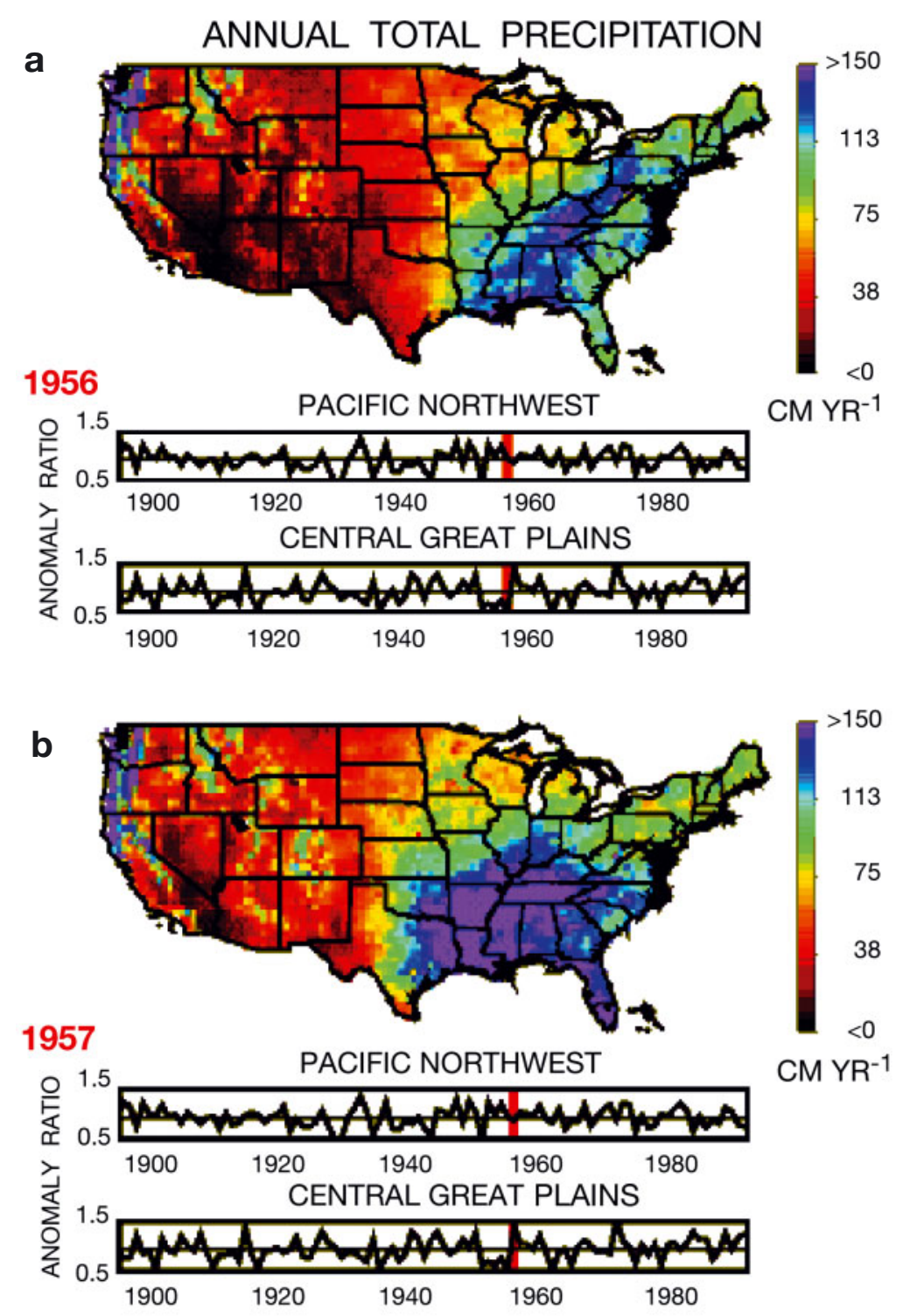

Fig. 9. VEMAP2 precipitation spatial and temporal variability patterns. Annual precipitation maps for (a) 1956 and (b) 1957 show years dominated by drought vs. high precipitation, respectively, across much of the southern and central US. Plots below each map show time series of annual anomaly ratios averaged for the Pacific Northwest (western Washington state) and Central Great Plains (Kansas and Nebraska); anomaly ratios are relative to the corresponding region's long-term spatial average. Vertical red bar in time plots indicates year mapped; horizontal line represents an anomaly ratio of 1.0 
Table 1. Regional trends (regression slopes) in the VEMAP2 Historical Climate Dataset from 1895-1993. Temperature trends for the annual mean (Mean), annual mean maximum (Max), and both annual and winter mean minimum (Min) are in ${ }^{\circ} \mathrm{C}$ per century. Trends for annual and summer total precipitation are in $\mathrm{mm}(\%)$ per century. ${ }^{*}$ Regression slope statistically $\neq 0 ; \alpha=0.05$. Regions are US National Assessment 'megaregions' (NAST 2001) (Fig. 12). Winter is December, January, February; summer is June, July, August. n/a = not analyzed

\begin{tabular}{|c|c|c|c|c|c|c|c|c|}
\hline & \multicolumn{4}{|c|}{ Temperature } & \multicolumn{4}{|c|}{ Precipitation } \\
\hline & \multicolumn{3}{|c|}{- Annual -} & \multirow{2}{*}{$\begin{array}{c}\text { Winter } \\
\text { Min }\end{array}$} & \multicolumn{2}{|c|}{ Annual } & \multicolumn{2}{|c|}{ Summer } \\
\hline & Mean & $\operatorname{Max}$ & Min & & $(\mathrm{mm})$ & $(\%)$ & $(\mathrm{mm})$ & $(\%)$ \\
\hline Northeast & 0.2 & 0.3 & 0.1 & -0.4 & 57 & $(5.4)$ & 2 & $(0.8)$ \\
\hline Southeast & -0.2 & -0.1 & -0.3 & -0.7 & $108^{*}$ & $(8.9)$ & 9 & $(-2.6)$ \\
\hline Midwest & 0.1 & 0.0 & 0.2 & 0.3 & $63^{*}$ & $(7.6)$ & 7 & $(2.3)$ \\
\hline Great Plains & 0.3 & 0.2 & $0.4^{*}$ & 0.5 & $52^{*}$ & (10.5) & 14 & (7.9) \\
\hline West & $0.3^{*}$ & 0.2 & $0.4^{*}$ & 0.9 & 37 & $(10.2)$ & 10 & (14.3) \\
\hline Pacific Northwest & 0.2 & 0.1 & $0.4^{*}$ & 0.8 & 25 & $(3.2)$ & $24^{*}$ & (29.3) \\
\hline Conterminous US & 0.2 & 0.1 & 0.2 & $\mathrm{n} / \mathrm{a}$ & $59^{*}$ & $(8.2)$ & $\mathrm{n} / \mathrm{a}$ & $(0.8)$ \\
\hline
\end{tabular}

a

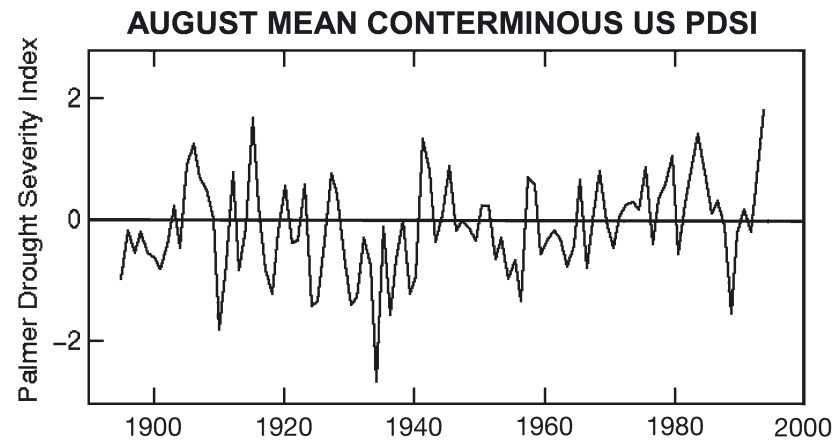

(Fig. 10b). Animations showing the progression of precipitation and temperature during the 20th century are available on the NCAR VEMAP web site (see Section 6).

\subsection{Dataset trends}

While the VEMAP2 dataset was not designed for critically evaluating climate trends during the 20th century, we analyzed linear trends in the gridded dataset because of its use in the recent USA National Assessment (NAST 2001) and because these trends influenced results from the VEMAP2 model intercomparison. Over the last century, the historical climate dataset showed weak linear trends in mean annual temperature and stronger trends in precipitation across the domain and for regions used in the National Assessment (Fig. 12, Table 1). The pattern of regional trends in annual mean temperature and precipitation was similar to that found by Karl et al. (1996) for the period 1900-1994 based on NCDC climate division averages, and by Hansen et al. (2001) for 1900-1999 based on HCN data. These studies also show that the trends were spatially more variable than can be resolved by the NAST. The VEMAP2

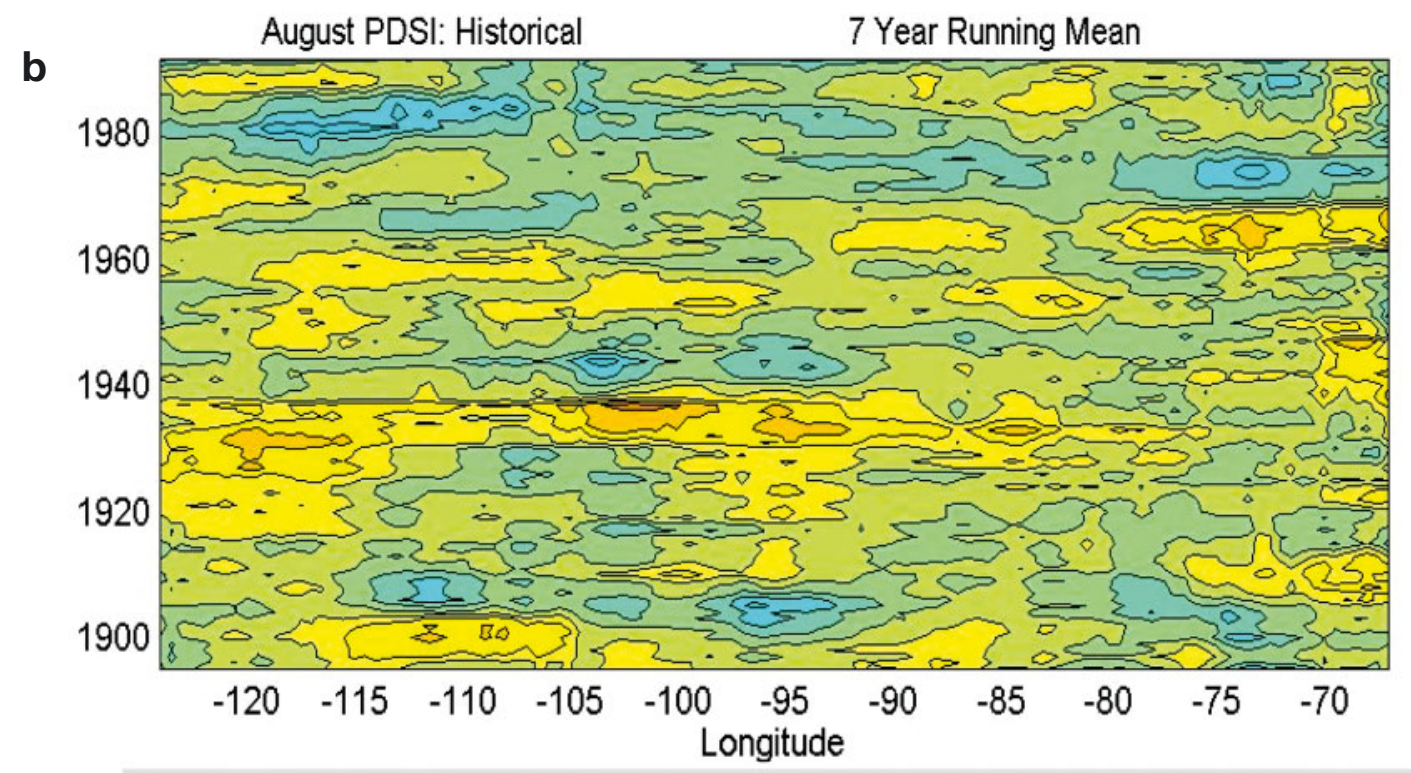

\section{PACIFIC G BASIN ROCKIES G PLAINS C LOWLNDS APPLS ATLANTIC N ENG}

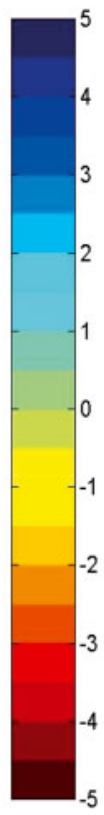

Fig. 10. (a) Time series of domain mean of Palmer Drought Severity Index (PDSI) for August. (b) Development of drought as shown by time-longitude section of PDSI in August. Vertical axis is time (year); horizontal axis is longitude $\left({ }^{\circ} \mathrm{W}\right)$. Mapped values are longitudinal averages for a given year, smoothed using a 7 yr running average. Note how droughts (yellow) in the far western and central US in the 1920s merge and intensify in the 1930s. Pacific: Pacific states; G Basin: Great Basin; Rockies: Rocky Mountains; G Plains: Great Plains; C Lowlnds: Central Lowlnds; Appls: Appalachians; Atlantic: Atlantic Coastal Plain; N Eng: New England 
a ANNUAL MAXIMUM TEMPERATURE ANOMALY

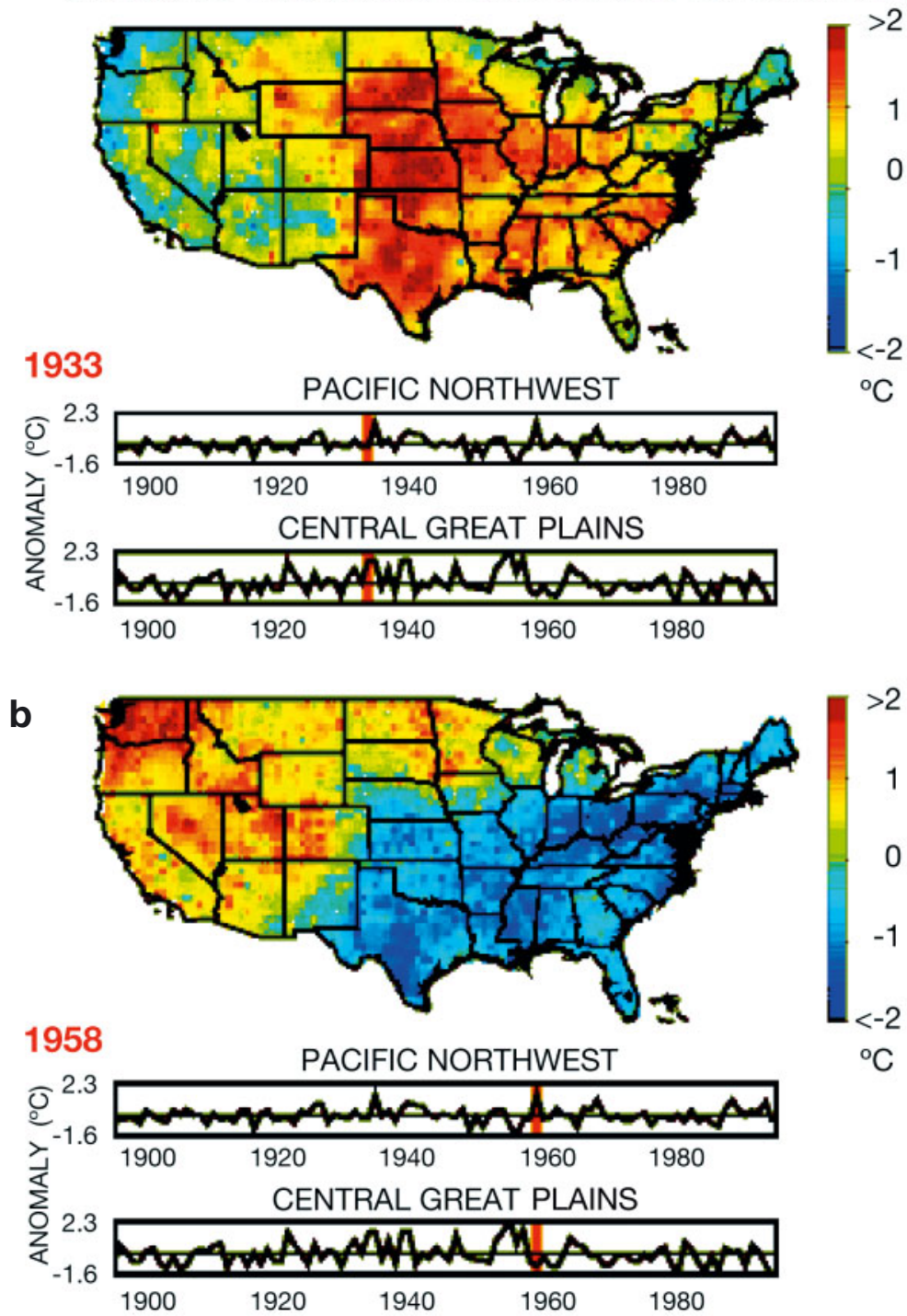

Fig. 11. As in Fig. 9, except for annual maximum temperature anomalies in years with opposite regional temperature anomaly patterns. (a) 1933,

(b) 1958. Anomalies in maps and time series are absolute differences (in

${ }^{\circ} \mathrm{C}$ ) from long-term averages. Horizontal line in the time plots represents a zero anomaly

1895-1993 mean annual temperature trend for the entire domain was $0.2^{\circ} \mathrm{C}$ per century, but was not statistically significant (ns). This trend was less than found by Hansen et al. (2001; $0.3^{\circ} \mathrm{C}$ per century) and Karl et al. (1996; $0.4^{\circ} \mathrm{C}$ per century) using slightly different periods and underlying datasets and different processes for spatial distribution of station data. The VEMAP annual precipitation trend was $6 \mathrm{~cm}(8 \%)$ per century and was statistically significant $(\mathrm{p}<0.05$; Table 1). This was similar to the $5 \%$ change from the first $70 \mathrm{yr}$ of the century to the 1970-1994 period found by Karl et al. (1996).
Temperature trends were positive for all regions, except in Southeast where there was a tendency for a decrease in temperatures (Table 1; e.g. Fig. 13b,h). The lack of a trend in the Midwest was a result of averaging across a region with strong positive trends in the north and negative trends in the south (Karl et al. 1996). In the Great Plains, West, and Pacific Northwest, positive trends in annual minimum temperature were significant $(\mathrm{p}<0.05)$ and greater than for maximum temperature, reflecting a reduced range in diurnal temperatures (Table 1); the Southeast showed the opposite pattern, resulting in a widening of diurnal temperature range. These patterns are consistent with analyses of diurnal temperature range trends across the USA for the second half of the 20th century (Plantico et al. 1990, Easterling et al. 1997). Regional winter minimum temperature trends tended to be stronger - whether positive or negative - than corresponding annual trends; however, winter trends were not significant.

Precipitation trends were also similar among regions, with significant (and generally the strongest) annual trends in the South-east, Midwest and Great Plains ( $\mathrm{p}<$ 0.05; Fig. 13a,d,e), and the strongest and significant summer trend in the Pacific Northwest ( $p<0.05$; Fig. 13f, Table 1). Increases in annual mean VP and decreases in SR in the Midwest and western regions (Table 2) are consistent with increases in precipitation (as expected, given that precipitation is used in the calculation of VP and SR). Although VP increased, RH changed little, largely because of nearly matched increases in saturation VP from higher temperatures. PDSI trends were positive, reflecting wetter conditions throughout the domain, with regionally significant trends in the Southeast, Great Plains, and West (Table 2).

The VEMAP2 dataset generally reflected long-term climate signals found in climate detection studies. Documenting these trends is important for interpreting VEMAP model outputs (Gordon et al. 2004) and other studies relying on these data (NAST 2001). However, even though trends in the dataset generally follow those in formal detection studies and although some trends were statistically significant, their significance with respect to a rigorous assessment of climate change is limited because of the likelihood of time-dependent biases in non-HCN data sources underlying the dataset (see Sections 3.1 and 7.1). 


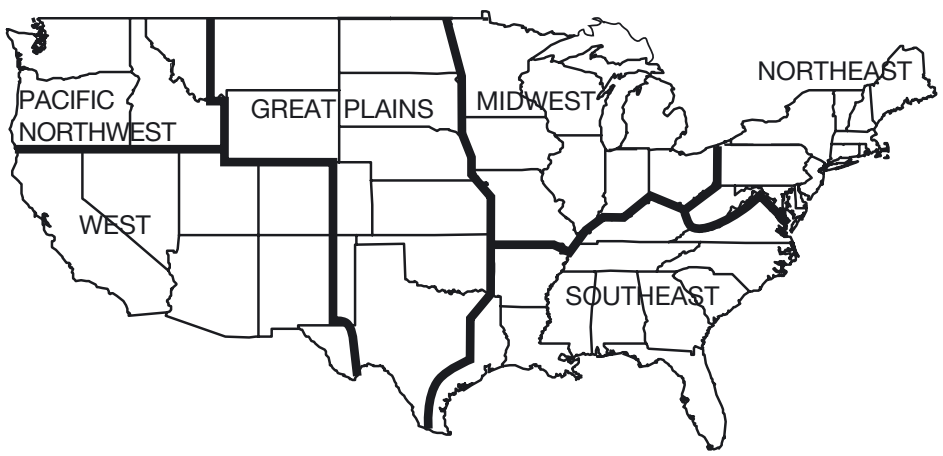

Fig. 12. US National Assessment 'megaregions' (NAST 2001) used in historical trend analysis (Tables 1 \& 2, Fig. 13)

\section{PUBLIC ACCESS - DATA AND TOOLS}

The VEMAP2 historical climate, derived datasets, and companion 21st century scenario climate sets (Kittel et al. 2000) are publicly available from data archives at the National Center for Atmospheric Research (www.cgd.ucar.edu/vemap/), Oak Ridge National Laboratory Distributed Active Archive Center (DAAC) (www-eosdis.ornl.gov/), and University of New Hampshire NASA/EOS-Webster (eos-webster.sr. unh.edu/). A user's guide is accessible online (Rosenbloom et al. 2002). Output from VEMAP2 model experiments and other input data used in these simulations are also downloadable from these sites. Other inputs include wind climatology, soil characteristics, potential natural vegetation, and current land cover (Kittel et al. 1995), as well as $\mathrm{CO}_{2}$ concentration. The $\mathrm{CO}_{2}$ record is a yearly global historical (and, after 1990, IS92a emission scenario-derived) time series of atmospheric $\mathrm{CO}_{2}$ concentration (Enting et al. 1994, Joos et al. 1996, Wigley 2000). Tools for access, analysis, and visualization of these data are available on the NCAR site.

\section{DATASET FEATURES AND LIMITATIONS}

\subsection{Caveats}

Assumptions, data, and methods used in the development of the gridded historical dataset impose limits on the use of the data in studies of environmental change across the conterminous USA. The dataset was designed to provide the best possible long-term and wall-to-wall representation of historical climate variability and change for use as inputs to ecological model simulations. This was accomplished by giving up qualities that are important for other applications. As a result, there are caveats for its use:
(1) The historical dataset was not designed for a definitive analysis of long-term climatic trends. The VEMAP2 dataset reflects the 20th century climate signal largely because longer station records underlying the dataset were primarily from the US HCN, with its detailed evaluation and correction for data inhomogeneities and other quality issues. However, incorporation of other data sources without such processing precludes the dataset's utility in climate change detection studies (see Section 3.1).

(2) The historical dataset is not an appropriate source for evaluating long-term changes in climatic variability, e.g. from the earlier to latter part of the 20th century, especially in the western USA. In the earlier part of the record at locations where station densities were low, the kriging prediction model tended to underpredict reconstructed time series variance (see Section 3.2.2).

(3) Daily records are not spatially autocorrelated in a manner that captures daily synoptic processes. As a result, the dataset is not appropriate for simulation of land surface processes that require cell-to-cell interactions on a daily basis (such as water basin runoff). While the climate dataset has proper spatial autocorrelation structure at the monthly timestep, the disaggregation process used to create the daily series was run independently for each grid cell (see Section 3.3).

(4) The daily dataset does not reflect observed daily records, but rather is synthetic. As a result, the dataset does not match actual historical information for day of key events (for example, last and first frost) nor for daily-derived statistics (such as growing-degree days) (see Section 3.3).

Alternative datasets for analysis of climatic trends in means and variances include the US HCN set (Easterling et al. 1996; as evaluated by Hansen et al. 2001). Temporally complete gridded or spatially extensive station daily datasets for the USA, based on observed

Table 2. Regional trends (regression slopes) in annual mean solar radiation (SR), vapor pressure (VP), relative humidity $(\mathrm{RH})$, and Palmer Drought Severity Index (PDSI); SR and VP: $\%$ change per century; RH: change in \% relative humidity per century; PDSI: PDSI units per century. SR, VP, and RH are calculated values (see Section 3.4). ${ }^{*}$ Regression slope statistically $\neq 0 ; \alpha=0.05$

\begin{tabular}{|lrrcc|}
\hline & SR & VP & RH & PDSI \\
\hline Northeast & 0.4 & 1 & 0 & 0.4 \\
Southeast & 0.7 & -1 & 0 & $0.6^{*}$ \\
Midwest & -0.8 & 1 & 1 & 0.6 \\
Great Plains & -0.8 & $4^{*}$ & 1 & $0.7^{*}$ \\
West & -0.7 & $6^{*}$ & 1 & $0.7^{*}$ \\
Pacific Northwest & $-1.4^{*}$ & $5^{*}$ & 1 & 0.5 \\
Conterminous US & -0.5 & $2^{*}$ & 1 & $0.6^{*}$ \\
\hline
\end{tabular}



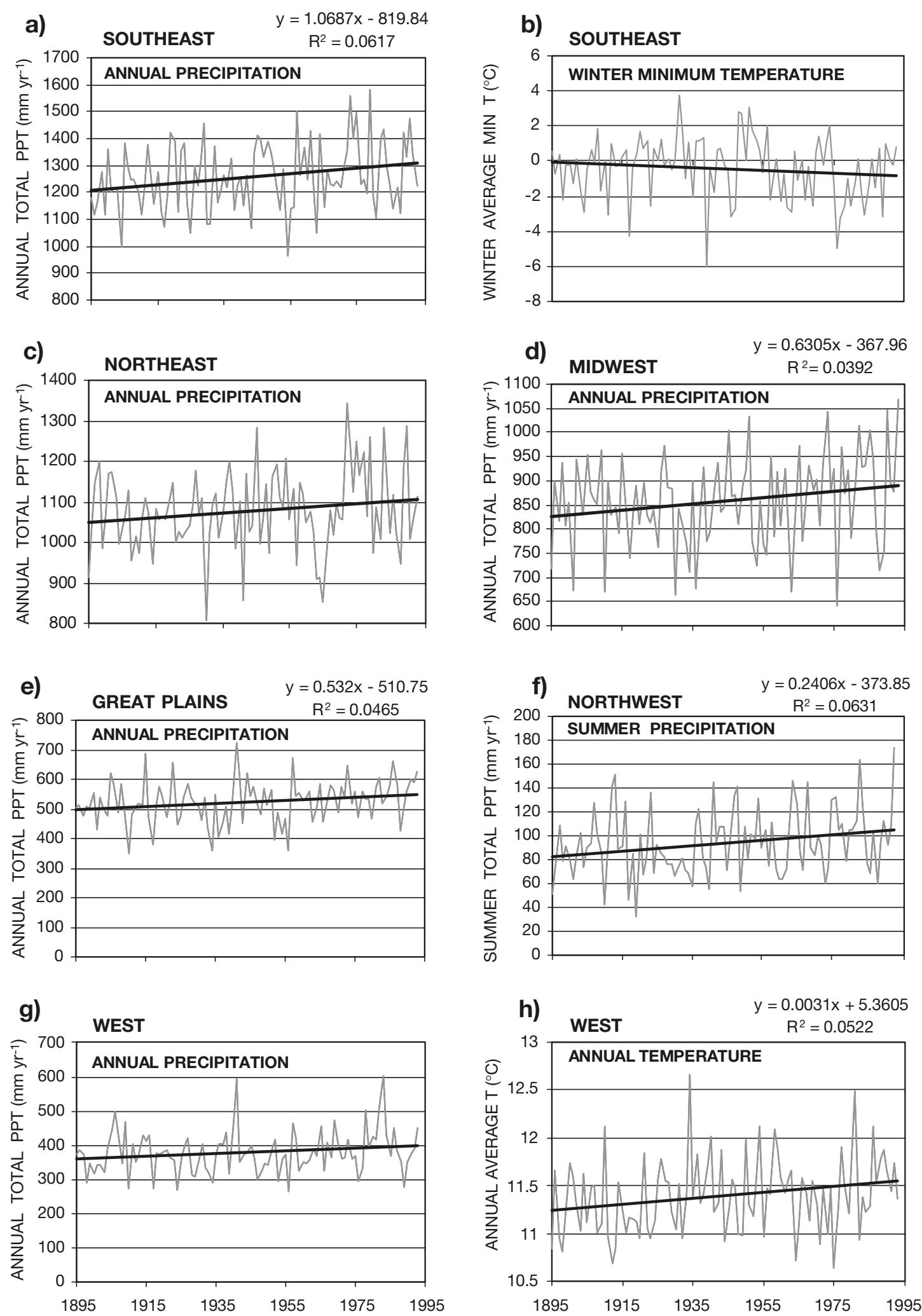

Fig. 13. Historical time series and trends for selected NAST regions (Fig. 12) and selected temperature and precipitation variables. $(\mathrm{a}, \mathrm{b})$ Southeast annual precipitation and winter mean minimum temperature; (c, d, e) Northeast, Midwest, and Great Plains annual precipitation; (f) Northwest: Pacific Northwest summer precipitation; $(g, h)$ West annual precipitation and mean temperature. Regression equations are given for slopes statistically $\neq 0(\alpha=0.05)$, where $y=$ climate variable and $x=$ year 
rather than synthetic records, include Thornton et al. (1997), Cooter et al. (2000), Eischeid et al. (2000), and Maurer et al. (2001).

\subsection{Summary}

Through analysis of spatial covariance structure and use of physically-guided statistical relationships among climate variables and physiographic controls, we created a long-term (99 yr) gridded dataset of monthly and daily precipitation, minimum and maximum temperature, solar radiation, and humidity. The dataset is: (1) temporally complete, with realistic representation of climate variability at daily through decadal scales; (2) spatially realistic, reflecting key climate gradients and spatial patterns of temporal variability across the domain at a resolution of $0.5^{\circ}$ latitude/longitude; and (3) physically consistent, maintaining relationships among climate variables, as well as with topography and other geographic factors. These features are crucial for reliable simulations of ecological processes across the conterminous USA for the 20th century. Keeping in mind dataset limitations, such simulations can be used to improve our understanding of how climate variability and change determine ecological outcomes and to evaluate ecosystem models against field and remotely sensed ecological observations.

Acknowledgements. VEMAP dataset development was sponsored by NASA Mission to Planet Earth, USDA Forest Service Global Change Research Program, and the Electric Power Research Institute (EPRI). Development of the kriging prediction model was supported by the Geophysical Statistics Project at the National Center for Atmospheric Research (NCAR), with funding from the National Science Foundation (NSF) - thanks to L. M. Berliner, R. Jones, Y. Zhang, and D. Nychka for their contributions. PRISM development and implementation was supported by USDA Natural Resources Conservation Service (NRCS) National Water and Climate Center and USDA Forest Service. We thank P. Pasteris and NRCS for access to SNOTEL time series data, T. Wigley for providing the $\mathrm{CO}_{2}$ dataset, $\mathrm{M}$. Parlange, R. Katz, and L. Mearns, along with S. Ferguson, for use of their version of WGEN, and D. Joseph and W. Spangler for assistance with meteorological datasets. NCAR is sponsored by NSF. Finally, thanks to L. Pitelka, A. Janetos, S. Fox, S. McNulty, and L. Williams for critical guidance.

\section{LITERATURE CITED}

Alley WM (1984) The Palmer Drought Severity Index: limitations and assumptions. J Clim Appl Meteorol 23:1100-1109

Barnes SL (1964) A technique for maximizing details in numerical weather map analysis. J Appl Meteorol 3: 396-409

Bristow KL, Campbell GS (1984) On the relationship between incoming solar-radiation and daily maximum and minimum temperature. Agric For Meteorol 31:159-166
Cooter EJ, Richman MB, Lamb PJ, Sampson DA (2000) A climate change database for biological assessments in the southeastern United States: development and case study. Clim Change 44:89-121

Cramer W, Fischer A (1996) Data requirements for global terrestrial ecosystem modeling. In: Walker B, Steffen W (eds) Global change and terrestrial ecosystems. Cambridge University Press, Cambridge, p 529-565

Cressie NAC (1993a) Statistics for spatial data. Wiley, New York

Cressie N(AC) (1993b) Aggregation in geostatistical problems. In: Soares A (ed) Geostatistics Troia '92, Vol 1. Kluwer Academic Publishers, Dordrecht, p 25-36

Daly C, Neilson RP, Phillips DL (1994) A statistical-topographic model for mapping climatological precipitation over mountainous terrain. J Appl Meteorol 33:140-158

Daly C, Johnson GL (1999) PRISM spatial climate layers: their development and use. In: Short course on topics in applied climatology, 79th Annu Meeting Am Meteorol Soc, 10-15 January, Dallas, TX. American Meteorological Society; available at: www.ocs.orst.edu/prism/prisguid.pdf

Daly C, Bachelet D, Lenihan JM, Neilson RP, Parton W, Ojima D (2000) Dynamic simulation of tree-grass interactions for global change studies. Ecol Appl 10:449-469

Daly C, Taylor GH, Gibson WP, Parzybok TW, Johnson GL, Pasteris P (2001) High-quality spatial climate data sets for the United States and beyond. Trans Am Soc Agric Engin 43:1957-1962

Daly C, Gibson WP, Taylor GH, Johnson GL, Pasteris P (2002) A knowledge-based approach to the statistical mapping of climate. Clim Res 22:99-113

Daly C, Gibson WP, Doggett M, Smith J, Taylor G (2004) Upto-date monthly climate maps for the conterminous United States. Proc 14th Am Meteorol Soc Conf Appl Climatol, 84th Annu Meeting Am Meteorol Soc Combined Preprints, Seattle, WA, January 13-16, Paper P5.1, CD-ROM. American Meteorological Society

Diaz HF, Bradley RS (1997) Temperature variations during the last century at high elevation sites. Clim Change 36: 253-279

Easterling DR, Karl TR, Mason EH, Hughes PY, Bowman DP, Daniels RC, Boden TA (1996) United States Historical Climatology Network (US HCN) monthly temperature and precipitation data. ORNL/CDIAC-87, NDP-019/R3. Carbon Dioxide Information Analysis Center, Oak Ridge National Laboratory, Oak Ridge, TN; available at National Center for Atmospheric Research (dataset ds565): http://dss.ucar. edu/datasets/ds565.0/

Easterling DR, Horton B, Jones PD, Peterson TC, and 7 others (1997) Maximum and minimum temperature trends for the globe. Science 277:364-367

Easterling DR, Karl TR, Lawrimore JH, Del Greco SA (1999) United States Historical Climatology Network daily temperature, precipitation, and snow data for 1871-1997. ORNL/CDIAC-118, NDP-070. Carbon Dioxide Information Analysis Center, Oak Ridge National Laboratory, Oak Ridge, TN; available at: http://cdiac.esd.ornl.gov/epubs/ ndp/ushcn/ndp070.html

Eischeid JK, Pasteris PA, Diaz HF, Plantico MS, Lott NJ (2000) Creating a serially complete, national daily time series of temperature and precipitation for the western United States. J Appl Meteorol 39:1580-1591

Elliott DL, Holladay CG, Barchet WR, Foote HP, Sandusky WF (1986) Wind energy resource atlas. Solar Technical Information Program, US Department of Energy, Washington, DC

Enting IE, Wigley TML, Heimann M (1994) Future emissions 
and concentrations of carbon dioxide: key ocean/atmosphere/land analyses. CSIRO Division of Atmospheric Research, technical paper 31

Fuentes M, Kittel TGF, Nychka D (2004) Sensitivity of ecological models to spatial-temporal estimation of their climate drivers: statistical ensembles for forcing. Ecol Appl (in press)

Gibson WP, Daly C, Kittel T, Nychka D, Johns C, Rosenbloom N, McNab A, Taylor G (2002) Development of a 103-year high-resolution climate data set for the conterminous United States. In: Proc 13th Am Meteorol Soc Conf Applied Climatol, Portland, OR, May 13-16. American Meteorological Society, 181-183; data available at: ftp.ncdc.noaa.gov/pub/data/prism100/

Gordon WG, Famiglietti JS, Fowler NA, Kittel TGF, Hibbard KA (2004) Validation of simulated runoff from VEMAP Phase II using observed streamflow: results from six terrestrial ecosystem models. Ecol Appl 14:527-545

Haas TC (1990) Lognormal and moving window methods of estimating acid deposition. J Am Stat Assoc 85:643-652

Haas TC (1995) Local prediction of a spatio-temporal process with an application to wet sulfate deposition. J Am Stat Assoc 90:1189-1199

Hansen J, Ruedy R, Sato M, Imhoff M, Lawrence W, Easterling D, Peterson T, Karl T (2001) A closer look at United States and global surface temperature change. J Geophys Res 106(D20):23947-23963

Hanson CL, Johnson GL (1998) GEM (Generation of weather elements for multiple applications): its application in areas of complex terrain. In: Kovar K, Tappeiner U, Peters NE, Craig RG (eds) Hydrology, water resources and ecology in headwaters. International Association of Hydrological Sciences (IAHS) Press, Wallingford, p 27-32

Joos F, Bruno M, Fink R, Siegenthaler U, Stocker TF, Le Quéré C (1996) An efficient and accurate representation of complex oceanic and biospheric models of anthropogenic carbon uptake. Tellus 48B:397-417

Karl TR, Knight RW, Easterling DR, Quayle RG (1996) Indices of climate change for the United States. Bull Am Meteorol Soc 77:279-292

Katz RW (1996) Use of conditional stochastic models to generate climate change scenarios. Clim Change 32:237-255

Kimball JS, Running SW, Nemani R (1997) An improved method for estimating surface humidity from daily minimum temperature. Agric For Meteorol 85:87-98

Kittel TGF, Rosenbloom NA, Painter TH, Schimel DS, VEMAP Modeling Participants (1995) The VEMAP integrated database for modeling United States ecosystem/vegetation sensitivity to climate change. J Biogeogr 22:857-862

Kittel TGF, Rosenbloom NA, Painter TH, Schimel DS, Fisher HH, Grimsdell AW, VEMAP Participants, Daly C, Hunt Jr ER (1996) The VEMAP Phase 1 database: an integrated input dataset for ecosystem and vegetation modeling for the conterminous United States. National Center for Atmospheric Research (NCAR), Boulder, CO. CD-ROM; available at www-eosdis.ornl.gov/ and www.cgd.ucar.edu/ vemap/

Kittel TGF, Rosenbloom NA, Kaufman C, Royle JA, 7 others and VEMAP2 Participants (2000) VEMAP Phase 2 historical and future scenario climate database. National Center for Atmospheric Research (NCAR), Boulder, CO; available at http://www-eosdis.ornl.gov/ and www.cgd.ucar.edu/ vemap/datasets.html

Kittel TGF, Rosenbloom NA, Royle JA, Aulenbach S, Fisher HH, Kaufman C, Daly C, Schimel DS, VEMAP2 Participants (2002) The VEMAP Phase 2 dataset for Alaska and adjacent Canada: gridded historical (1922-1996) and future scenario climates. National Center for Atmospheric
Research (NCAR), Boulder, $\mathrm{CO}$; available at www. cgd.ucar.edu/vemap/datasets.html

Marks D (1990) The sensitivity of potential evapotranspiration to climate change over the continental United States. In: Gucinski H, Marks D, Turner DP (eds) Biospheric feedbacks to climate change: the sensitivity of regional trace gas emissions, evapotranspiration, and energy balance to vegetation redistribution. EPA/600/3-90/078. US Environmental Protection Agency, Corvallis, OR, p IV-1-IV-31

Marks D, Dozier J (1992) Climate and energy exchange at the snow surface in the alpine region of the Sierra Nevada: 2. Snow cover energy balance. Wat Resour Res 28:3043-3054

Maurer EP, O'Donnell GM, Lettenmaier DP, Roads JO (2001) Evaluation of the land surface water budget in NCEP/ NCAR and NCEP/DOE reanalyses using an off-line hydrologic model. J Geophys Res Atmos 106(D16): 17841-17862; see also www.hydro.washington.edu/ Lettenmaier/gridded_data/

Mearns LO, Rosenweig C, Goldberg R (1996) The effect of changes in daily and interannual variability on CERESWheat: a sensitivity study. Clim Change 32:257-292

NAST (National Assessment Synthesis Team) (eds) (2001) Climate change impacts for the United States: the potential consequences of climate variability and change. Foundation document. US Global Change Research Program, Washington, DC. Cambridge University Press, Cambridge

NCDC (National Climatic Data Center) (undated a) U.S. control summary of month, 1851(1931)-continuing (cooperative network). NCDC numeric data collection TD 3220, US Department of Commerce; National Center for Atmospheric Research (dataset ds560.0), available at: http:// dss.ucar.edu/datasets/ds560.0/

NCDC (National Climatic Data Center) (undated b) U.S. first order summary of day, 1884(1948)-continuing. NCDC numeric data collection TD 3210, US Department of Commerce; National Center for Atmospheric Research (dataset ds509.0), available at: http://dss.ucar.edu/datasets/ds509.0/

NCDC (National Climatic Data Center) (undated c) U.S. control summary of day, 1890(1948)-continuing (cooperative network). NCDC numeric data collection TD 3200, US Department of Commerce; National Center for Atmospheric Research (dataset ds510.0), available at: http://dss.ucar.edu/datasets/ds510.0/

NCDC (National Climatic Data Center) (1994a) 1961-1990 monthly sequential temperature and precipitation data. CD-ROM: U.S. divisional and station climatic data and normals, vol 1. NCDC numeric data collection TD 9641, US Department of Commerce, Asherville, NC

NCDC (National Climatic Data Center) (1994b) 1951-1980 monthly sequential temperature and precipitation data. CDROM: U.S. divisional and station climatic data and normals, vol 1. NCDC numeric data collection TD 9641, US Department of Commerce, Asherville, NC

New M, Hulme M, Jones P (2000) Representing twentiethcentury space-time climate variability. Part II: Development of 1901-96 monthly grids of terrestrial surface climate. J Clim13:2217-2238

NRCS (Natural Resources Conservation Service) (1996) Monthly SNOTEL historical data. National Water and Climate Center, USDA Natural Resources Conservation Service, Portland $\mathrm{OR}_{i}$ unpublished dataset; related dataset available at: www.wcc.nrcs.usda.gov/water/snow/ snowhist.html

NREL (National Renewable Energy Laboratory) (1993) Solar and Meteorological Surface Observation Network, 1961-90. US Department of Energy, National Renewable Energy Laboratory, Golden, CO 
Palmer WC (1965) Meteorological drought. Research paper no. 45, US Department of Commerce Weather Bureau, Washington, DC

Pan Y, Melillo JM, McGuire AD, Kicklighter DW, 7 others and VEMAP Members (1998) Modeled responses of terrestrial ecosystems to elevated atmospheric $\mathrm{CO}_{2}$ : a comparison of simulations by the biogeochemistry models of the Vegetation/Ecosystem Modeling and Analysis Project (VEMAP). Oecologia 114:389-404

Parlange MB, Katz RW (2000) An extended version of the Richardson model for simulating daily weather variables. J Appl Meteorol 39:610-622

Parton WJ, Schimel DS, Ojima DS, Cole CV (1994) A general model for soil organic matter dynamics: sensitivity to litter chemistry, texture and management. In: Bryant RB, Arnold RW (eds) Quantitative modeling of soil forming processes. Soil Sci Soc Am Spec Publ 39:137-167

Plantico MS, Karl TR, Kukla G, Gavin J (1990) Is recent climate change across the United States related to rising levels of anthropogenic greenhouse gases? J Geophys Res 95(D10):16617-16637

Post WM, King A, Wullschleger S (1997) Historical variations in terrestrial biospheric carbon storage. Global Biogeochem Cycles 11:99-109

Richardson CW (1981) Stochastic simulation of daily precipitation, temperature and solar radiation. Wat Resour Res $17: 182-190$

Rosenbloom N, Kittel TGF (1996) A user's guide to the VEMAP Phase I database. NCAR technical note NCAR/ TN-431+IA, National Center for Atmospheric Research, Boulder, $\mathrm{CO}$; updated version available at www.cgd.ucar. edu/vemap/users_guide.html

Rosenbloom N, Kittel TGF, Kaufman C, Aulenbach S (2002) User's guide to the VEMAP Phase 2 database [revised]. National Center for Atmospheric Research, Boulder, CO; available at www.cgd.ucar.edu/vemap/users_guideV2.html

Royle JA (2000) Multivariate spatial models. In: Berliner LM, Nychka D, Hoar T (eds) Studies in the atmospheric sciences. Springer-Verlag New York, p 23-43

Running SW, Nemani RR, Hungerford RD (1987) Extrapolation of synoptic meteorological data in mountainous terrain and its use for simulating forest evapotranspiration and photosynthesis. Can J For Res 17:472-483

Schimel DS, VEMAP Participants, Braswell BH (1997) Spatial variability in ecosystem processes at the continental scale: models, data, and the role of disturbance. Ecol Monogr 67: 251-271

Editorial responsibility: Robert Davis, Charlotteville, Virginia, USA
Schimel D, Melillo J, Tian H, McGuire AD and 11 others (2000) Contribution of increasing $\mathrm{CO}_{2}$ and climate to carbon storage by ecosystems of the United States. Science 287:2004-2006

Sitch S, Smith B, Prentice IC, Arneth A and 8 others (2003) Evaluation of ecosystem dynamics, plant geography and terrestrial carbon cycling in the LPJ dynamic global vegetation model. Global Change Biol 9:161-185

Tian H, Melillo JM, Kicklighter DW, McGuire AD, Helfrich J (1999) The sensitivity of terrestrial carbon storage to historical climate variability and atmospheric $\mathrm{CO}_{2}$ in the United States. Tellus 51B:414

Thornton PE, Running SW, White MA (1997) Generating surfaces of daily meteorological variables over large regions of complex terrain. J Hydrol 190:214-251; data available at: www.daymet.org/

Thornton PE, Running SW (1999) An improved algorithm for estimating incident daily solar radiation from measurements of temperature, humidity, and precipitation. Agric For Meteorol 93:211-228

Thornton PE, Hasenauer H, White MA (2000) Simultaneous estimation of daily solar radiation and humidity from observed temperature and precipitation: an application of complex terrain in Austria. Agric For Meteorol 104: $255-271$

Thornton PE, Law BE, Gholz HL, Clark KL and 8 others (2002) Modeling and measuring the effects of disturbance history and climate on carbon and water budgets in evergreen needleleaf forests. Agric For Meteorol 113:185-222

Trenberth KE, Hurrell JW (1994) Decadal atmosphere-ocean variations in the Pacific. Clim Dyn 9:303-319

VEMAP Members (1995) Vegetation/Ecosystem Modeling and Analysis Project (VEMAP): comparing biogeography and biogeochemistry models in a continental-scale study of terrestrial ecosystem responses to climate change and $\mathrm{CO}_{2}$ doubling. Global Biogeochem Cycles 9:407-437

Wigley TML (2000) Stabilization of $\mathrm{CO}_{2}$ concentration levels. In: Wigley TML, Schimel DS (eds) The global carbon cycle. Cambridge University Press, Cambridge, p 258-276

Wilks DS (1989) Conditioning stochastic daily precipitation models on total monthly precipitation. Wat Resour Res 25: 1429-1439

Yates DN, Kittel TGF, Cannon RF (2000) Comparing the correlative Holdridge model to mechanistic biogeographical models for assessing vegetation distribution response to climatic change. Clim Change 44:59-87

Submitted: February 26, 2003; Accepted: July 16, 2004 Proofs received from author(s): September 20, 2004 